Review

\title{
Two-Photon Imaging to Unravel the Pathomechanisms Associated with Epileptic Seizures: A Review
}

\author{
Luqman Khan ${ }^{1,+}$, Rick van Lanen $2,3,+\left(\mathbb{D}\right.$, Govert Hoogland ${ }^{2,3}$, Olaf Schijns $2,3,4$, Kim Rijkers ${ }^{2,3,4}$, \\ Dimitrios Kapsokalyvas ${ }^{5,6}(\mathbb{D}$, Marc van Zandvoort $7,8,9, \ddagger$ and Roel Haeren $2,3,10, *, \ddagger(\mathbb{D})$
}

1 Faculty of Health Medicine and Life Sciences, Maastricht University, 6229 ER Maastricht, The Netherlands; 1.khan@student.maastrichtuniversity.nl

2 Department of Neurosurgery, Maastricht University Medical Center, P.O. Box 5800, 6202 AZ Maastricht, The Netherlands; rick.van.lanen@mumc.nl (R.v.L.); g.hoogland@maastrichtuniversity.nl (G.H.); o.schijns@mumc.nl (O.S.); kim.rijkers@mumc.nl (K.R.)

3 School for Mental Health and Neuroscience (MHeNs), Maastricht University, 6229 ER Maastricht, The Netherlands

4 Academic Center for Epileptology (ACE), Maastricht University Medical Center, P.O. Box 5800, 6202 AZ Maastricht, The Netherlands

5 Department of Genetics and Cell Biology, Maastricht University Medical Center, P.O. Box 616, 6200 MD Maastricht, The Netherlands; d.kapsokalyvas@maastrichtuniversity.nl

6 Interdisciplinary Center for Clinical Research (IZKF), University Hospital RWTH Aachen, 52062 Aachen, Germany

7 Department of Molecular Cell Biology, School for Mental Health and Neuroscience (MHeNS), Maastricht University Medical Center, P.O. Box 616, 6200 MD Maastricht, The Netherlands; mamj.vanzandvoort@maastrichtuniversity.nl

check for updates

Citation: Khan, L.; van Lanen, R.; Hoogland, G.; Schijns, O.; Rijkers, K.; Kapsokalyvas, D.; van Zandvoort, M.; Haeren, R. Two-Photon Imaging to Unravel the Pathomechanisms Associated with Epileptic Seizures: A Review. Appl. Sci. 2021, 11, 2404. https://doi.org/10.3390/app11052404

Academic Editors: Stefano Selci and Qi-Huang Zheng

Received: 31 January 2021

Accepted: 4 March 2021

Published: 8 March 2021

Publisher's Note: MDPI stays neutral with regard to jurisdictional claims in published maps and institutional affiliations.

Copyright: (c) 2021 by the authors. Licensee MDPI, Basel, Switzerland. This article is an open access article distributed under the terms and conditions of the Creative Commons Attribution (CC BY) license (https:/ / creativecommons.org/licenses/by/ $4.0 /)$.
8 Department of Molecular Cell Biology, School for Cardiovascular Diseases (CARIM), Maastricht University Medical Center, P.O. Box 616, 6200 MD Maastricht, The Netherlands

9 Institute for Molecular Cardiovascular Research (IMCAR), University Hospital RWTH Aachen, 52074 Aachen, Germany

10 Department of Neurosurgery, Helsinki University Hospital, P.O. Box 4, 00014 Helsinki, Finland

* Correspondence: roel.haeren@mumc.nl; Tel.: +314-3387-6052

+ These authors contributed equally to this work and share first authorship.

$\ddagger$ These authors share last authorship.

Abstract: Despite extensive research, the exact pathomechanisms associated with epileptic seizure formation and propagation have not been elucidated completely. Two-photon imaging (2PI) is a fluorescence-based microscopy technique that, over the years, has been used to evaluate pathomechanisms associated with epileptic seizures and epilepsy. Here, we review previous applications of 2PI in epilepsy. A systematic search was performed in multiple literature databases. We identified 38 publications that applied 2PI in epilepsy research. These studies described models of epileptic seizure propagation; anatomical changes and functional alterations of microglia, astrocytes, and neurites; and neurometabolic effects that accompany seizures. Moreover, various neurovascular alterations that accompany seizure onset and ictal events, such as blood vessel responses, have been visualized using 2PI. Lastly, imaging and quantitative analysis of oxidative stress and the aggregation of lipofuscin in the neurovasculature have been accomplished with 2PI. Cumulatively, these papers and their reported findings demonstrate that $2 \mathrm{PI}$ is an especially well-suited imaging technique in the domain of epilepsy research, and these studies have significantly improved our understanding of the disorder. The application of 2PI provides ample possibilities for future research, most interestingly on human brains, while also stretching beyond the field of epilepsy.

Keywords: two-photon; 2-photon; imaging; microscopy; epilepsy; seizures; neurovascular

\section{Introduction}

Two-photon imaging (2PI) is a fluorescence-based laser scanning microscopy technique commonly used in studies across various fields of research, including neurobiology, 
embryology, and tissue engineering [1,2]. In principle, it involves two infrared photons simultaneously exciting a single fluorophore in a sample, thereby causing it to emit light in a specific wavelength region, also called fluorescence emission spectrum. This fluorescence is normally detected in a wavelength region close to the maximum of this spectrum, allowing the sample to be identified based on its specific fluorescent characteristics. Compared to confocal single-photon microscopy, the main advantages of 2PI include reduced damage of tissues, allowing intravital studies, greater penetration depth of up to $2 \mathrm{~mm}$ in the brain, and ex vivo deep tissue imaging. Simultaneously, it maintains the typical characteristics of confocal microscopy, such as optical slicing capabilities with the option to perform 3-dimensional (3D) structural visualization and quantification, and its high subcellular resolution of around 400 nanometers [3-5]. We also note that, while many clinical techniques, such as ultrasound, CT, PET, and MRI, can penetrate much deeper in tissues, their resolution is up to a factor 1000 worse and cannot image at a subcellular level. We conclude that, despite the multiple applications of 2PI in various scientific fields, there might be further potential for the application of 2PI in epilepsy research.

There is an enormous need to further understand the pathophysiology of epilepsy. Being one of the most common neurological disorders, epilepsy accounts for the highest disability-adjusted life years [6], affecting around sixty million people worldwide [7], of whom $30-40 \%$ are drug-resistant [8]. The societal burden of chronic epilepsy is massive and encompasses around $80 \%$ of total epilepsy-related costs [6].

In recent years, epilepsy research has made a shift toward a vascular-centered concept of epileptogenesis [9-12]. This has resulted in the identification of an important role of neurovascular alterations [13] and increased blood-brain barrier permeability in the pathophysiology of epilepsy [14-16]. Indeed, recent reports have emphasized similarities between alterations in epilepsy and microvascular dysfunction [17-19]. Additionally, oxidative stress has been implicated in epilepsy—as this process has been shown to induce structural cell damage and to facilitate the formation of lipofuscin, which itself also induces cellular damage [20-22]. Nevertheless, further research into the different aspects of the pathophysiology of epilepsy is needed to connect these areas.

In this regard, the application of 2PI in epilepsy research entails high potential to improve our understanding of seizure-induced anatomical and pathophysiological changes across different scales, ranging from neuronal structures to neuronal microcircuits and the neurovasculature [23,24]. Moreover, advances in two-photon laser scanning have enabled in vivo imaging of the brain while preserving the natural neuronal environment [25]. Consequently, pathological activity in these in vivo models may represent epileptic conditions more accurately [1]. Furthermore, two-photon uncaging is a powerful technique that is of significance in epilepsy research. It essentially involves the use of the two-photon excitation laser to photolyse or activate certain biological compounds such as neurotransmitters while also allowing the visualization of the immediate effects of this photochemical excitation without any other interference. In addition, fluorescence lifetime imaging, a technique based on differences in the decay rates (on the nanoseconds time-scale) of fluorophores in samples rather than intensity [26] can be advantageous when studying specific types of environments and the effects thereof on fluorophore. Lifetime imaging can be used with two-photon excitation (2P-FLIM) as well as with confocal microscopy and multiphoton tomography. When probing molecular environments wherein intensity-based measurements alone are often insufficient, fluorescence lifetime-based measurements may be capable of yielding additional data [26]. Finally, the development of a wide range of fluorescent markers has made it possible to study various aspects of the pathophysiology of epilepsy, such as neurotransmitter levels [27,28], metabolism [28,29], pathological neuronal activity [27], and hypersynchronous network firing [30].

Previous studies that employed 2PI to evaluate the mechanisms associated with epileptic seizures have indeed contributed significantly to our understanding of this complex disorder. Here, we aim to review previous applications of 2PI in epilepsy research and to 
delineate the potential applications of 2PI in future research on epilepsy, particularly in relation to the pathophysiological role of the cerebral microvasculature.

\section{Materials and Methods}

\subsection{Search and Selection Strategy}

To acquire the relevant literature, the PubMed, JSTOR, and Embase databases were searched using a structured search strategy. The following Boolean search was last conducted on 9 December 2020: ((epilepsy OR seizure OR epileptic) AND (("fluorescence lifetime imaging") OR (two-photon OR "two photon")). Duplicates were removed, and the identified articles were screened for inclusion based on title and abstract by two researchers (L.K. and R.L.) independently. See Figure 1 for a flow diagram representation of the search strategy.

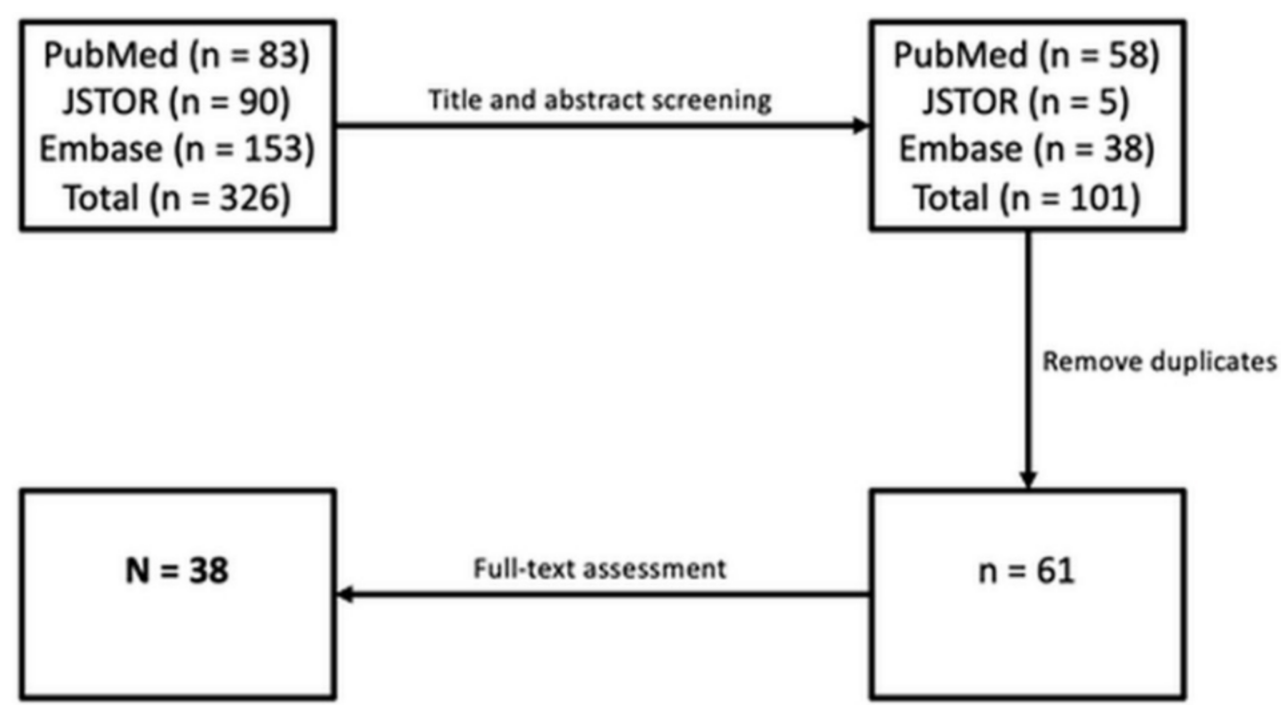

Figure 1. Flow diagram describing the literature search strategy employed.

Of the remaining papers, we retrieved and reviewed the full text for inclusion. Reference lists were assessed for potential articles of interest. The following inclusion criteria were applied: studies investigating mechanisms associated with epilepsy and studies that employ 2PI. Additionally, we applied the following exclusion criteria: intervention studies; studies investigating diagnostic, therapeutic, or epidemiological aspects of epilepsy; review papers; conference abstracts and unpublished material; and studies investigating syndromes in which epileptic seizures are not the primary symptom (e.g., Rett syndrome).

\subsection{Data Extraction}

The selected publications were then divided into six groups based on subject: epileptic network propagation (Table 1), microglia (Table 2), astrocytes (Table 3), neurovasculature (Table 4), neurites (Table 5), and neurometabolism (Table 6). Two types of tables were then generated: study characteristics (see Supplementary Materials: Table S1 Epileptic Network Propagation, Table S2 microglia, Table S3 Astrocytes, Table S4 Neurovasculature, Table S5 Neurites, Table S6 Neurometabolism) and data extraction tables. The study characteristics table lists specific features of each paper, such as the title, authors, year of publication, animal model(s) used, study design, and the pharmacological agent used to induce experimental seizures. The data extraction tables contain information on the 2PI technique, including the type of microscope and laser, the excitation wavelength of the laser, the type of objective used and its numerical aperture, and a description of what was visualized. 


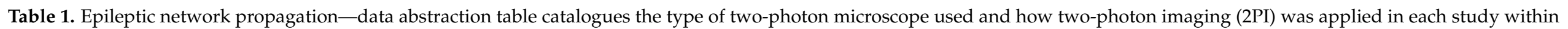
this group of publications.

\begin{tabular}{|c|c|c|}
\hline Title and Authors & Microscope & Application \\
\hline $\begin{array}{l}\text { Role of inhibitory control in modulating focal seizure spread (Liou } \\
\qquad \text { et al. [31]) }\end{array}$ & $\begin{array}{c}\text { Bruker } \\
\text { Ti:Sapphire laser (Coherent) } \\
940 \mathrm{~nm} \\
25 \times \text { water immersion objective (1.05 NA) }\end{array}$ & $\begin{array}{l}\text { Two-photon calcium imaging of GCaMP6F-positive } \\
\text { interneurons was performed. Regions of interest were } \\
\text { registered to target GCaMP6F-expressing } \\
\text { parvalbumin interneurons. }\end{array}$ \\
\hline $\begin{array}{l}\text { Acute focal seizures start as local synchronizations of neuronal } \\
\text { ensembles (Wenzel et al. [32]) }\end{array}$ & $\begin{array}{c}\text { Bruker } \\
\text { Ti:Sapphire laser (Coherent) } \\
940 \mathrm{~nm} \\
25 \times \text { water immersion objective (1.05 NA) }\end{array}$ & $\begin{array}{l}\text { Two-photon calcium imaging was used to visualize the } \\
\text { activity of cortical neurons in layers II/III of mouse } \\
\text { primary somatosensory cortex in vivo. }\end{array}$ \\
\hline $\begin{array}{l}\text { Reliable and elastic propagation of cortical seizures in vivo (Wenzel } \\
\text { et al. [33]) }\end{array}$ & $\begin{array}{c}\text { Bruker } \\
\text { Ti:Sapphire laser (Coherent) } \\
940 \mathrm{~nm} \\
25 \times \text { water immersion objective (1.05 NA) }\end{array}$ & $\begin{array}{l}\text { The activity of cortical neurons was recorded in vivo by } \\
\text { imaging changes in fluorescence (OGB-1 or } \\
\text { AAV1-Syn-GCaMP6 calcium indicators). }\end{array}$ \\
\hline Pyramidal cells accumulate chloride at seizure onset (Lillis et al. [34]) & $\begin{array}{c}\text { BioRad Radiance } 2000 \mathrm{MP} \\
\text { Ti:Sapphire laser (Spectra) } \\
860 \mathrm{~nm} \\
20 \times \text { water immersion objective (0.95 NA) }\end{array}$ & $\begin{array}{c}\text { Two-photon calcium imaging of mouse hippocampal slices } \\
\text { was performed to visualize epileptiform activity in } \\
\text { neuronal populations. }\end{array}$ \\
\hline $\begin{array}{l}\text { Fast spiking interneuron control of seizure propagation in a cortical } \\
\text { slice model of focal epilepsy (Cammarota et al. [35]) }\end{array}$ & $\begin{array}{c}\text { Prairie Ultima } \\
750 \mathrm{~nm}, 920 \mathrm{~nm}\end{array}$ & $\begin{array}{l}\text { Two-photon calcium imaging of rat and transgenic mouse } \\
\text { cortico-hippocampal slices was performed. }\end{array}$ \\
\hline $\begin{array}{l}\text { Epileptiform activity in the mouse visual cortex interferes with } \\
\text { cortical processing in connected areas (Petrucco et al. [36]) }\end{array}$ & $\begin{array}{c}\text { Prairie Ultima } \\
\text { Ti:Sapphire laser (Coherent) } \\
890 \mathrm{~nm} \\
\text { 20× water immersion objective }\end{array}$ & $\begin{array}{l}\text { Two-photon calcium imaging was used to visualize } \\
\text { pyramidal cells expressing GCaMP6f } 200-250 \mu \mathrm{m} \text { below } \\
\text { the cortical surface in transgenic mice. }\end{array}$ \\
\hline $\begin{array}{l}\text { GABAergic inhibition shapes interictal dynamics in awake epileptic } \\
\text { mice (Muldoon et al. [37]) }\end{array}$ & $\begin{array}{l}\text { TriM Scope II La Vision Biotech } \\
\text { Ti:Sapphire laser (Coherent) } \\
920 \mathrm{~nm} \\
\text { 16× water immersion objective } \\
(0.80 \mathrm{NA})\end{array}$ & $\begin{array}{l}\text { GCaMP5G was expressed in CA1 hippocampal cells, and } \\
\text { 2PI of spontaneous interictal activity was performed } \\
\text { in vivo over several days to map cellular recruitment. }\end{array}$ \\
\hline $\begin{array}{l}\text { Nanoparticle-based fluoroionophore for analysis of potassium ion } \\
\text { dynamics in 3D tissue models and in vivo (Muller et al. [38]) }\end{array}$ & $\begin{array}{l}\text { Olympus FV1000 Confocal } \\
633 \mathrm{~nm} \\
60 \times \text { oil immersion objective }\end{array}$ & $\begin{array}{l}\text { Seizures were monitored in brain slices using the } \\
\mathrm{K}^{+} \text {-sensitive fluoroionophore FI3. }\end{array}$ \\
\hline
\end{tabular}


Table 1. Cont.

\begin{tabular}{|c|c|c|}
\hline Title and Authors & Microscope & Application \\
\hline $\begin{array}{l}\text { Evolution of epileptiform activity in zebrafish by statistical-based } \\
\text { integration of electrophysiology and 2-photon } \mathrm{Ca}^{2+} \text { imaging } \\
\text { (Cozzolino et al. [39]) }\end{array}$ & $\begin{array}{c}\text { Prairie Ultima } \\
\text { Ti:Sapphire laser (Coherent) } \\
920 \mathrm{~nm} \\
20 \times \text { water immersion objective } \\
(1.00 \mathrm{NA})\end{array}$ & $\begin{array}{l}\text { In vivo two-photon calcium imaging was performed to } \\
\text { quantitatively evaluate the spatial recruitment of neuronal } \\
\text { populations during epileptic activity. }\end{array}$ \\
\hline $\begin{array}{l}\text { Combined two-photon imaging, electrophysiological, and anatomical } \\
\text { investigation of the human neocortex in vitro (Kerekes et al. [40]) }\end{array}$ & $\begin{array}{c}\text { Femto2D-uncage (Femtonics) } \\
\text { Ti:Sapphire laser } \\
\text { 830, } 840 \mathrm{~nm} \\
\text { 20× objective } \\
(1.00 \mathrm{NA})\end{array}$ & $\begin{array}{l}\text { Two-photon imaging and glutamate uncaging were performed } \\
\text { to obtain spatial information about network mechanisms } \\
\text { underlying neural synchronous population activity in human } \\
\text { postoperative neocortical slices. }\end{array}$ \\
\hline $\begin{array}{l}\text { Evolution of network synchronization during early epileptogenesis } \\
\text { parallels synaptic circuit alterations (Lillis et al. [41]) }\end{array}$ & $\begin{array}{c}\text { BioRad Radiance } 2000 \mathrm{MP} \\
\text { Ti:Sapphire laser (Spectra) } \\
860 \mathrm{~nm} \\
\begin{array}{c}\text { 20× water immersion objective } \\
(0.95 \mathrm{NA})\end{array}\end{array}$ & $\begin{array}{c}\text { Two-photon calcium imaging of neurons in the pyramidal } \\
\text { layer of mouse hippocampal slices was performed to } \\
\text { investigate neuronal participation in seizure and } \\
\text { interictal activity. }\end{array}$ \\
\hline
\end{tabular}


Table 2. Microglia-data abstraction table catalogues the type of two-photon microscope used and how 2PI was applied in each study within this group of publications.

\begin{tabular}{|c|c|c|}
\hline Title and Authors & Microscope & Application \\
\hline $\begin{array}{l}\text { Microglial proliferation and monocyte infiltration contribute to } \\
\text { microgliosis following status epilepticus (Feng et al. [42]) }\end{array}$ & $\begin{array}{c}\text { Scientifica Ltd. } \\
\text { Ti:Sapphire laser (Spectra) } \\
1040 \mathrm{~nm} \\
40 \times \text { water immersion objective } \\
(0.80 \mathrm{NA})\end{array}$ & $\begin{array}{l}\text { Microglia in coronal brain slices containing the hippocampus } \\
\text { were analyzed using 2PI to determine seizure-induced changes } \\
\text { in morphology. }\end{array}$ \\
\hline $\begin{array}{l}\text { P2Y12R-dependent translocation mechanisms gate the } \\
\text { changing microglial landscape (Eyo et al. [43]) }\end{array}$ & $\begin{array}{c}\text { Scientifica Ltd. } \\
\text { Ti:Sapphire laser (Spectra) } \\
900 \mathrm{~nm} \\
40 \times \text { water immersion objective } \\
(0.80 \mathrm{NA})\end{array}$ & $\begin{array}{l}\text { In vivo two-photon images were collected from } 50-120 \mu \mathrm{m} \\
\text { into the brain to study microglial activation. }\end{array}$ \\
\hline $\begin{array}{l}\text { Regulation of physical microglia-neuron interactions by } \\
\text { fractalkine signaling after status epilepticus (Eyo et al. [44]) }\end{array}$ & $\begin{array}{c}\text { Scientifica Ltd. } \\
\text { Ti:Sapphire laser (Spectra) } \\
900 \mathrm{~nm} \\
40 \times \text { water immersion objective } \\
(0.80 \mathrm{NA})\end{array}$ & $\begin{array}{l}\text { Microglia and neurons in coronal brain slices were imaged and } \\
\text { quantification of process convergence events was performed } \\
\text { manually through time-lapse movies. }\end{array}$ \\
\hline $\begin{array}{l}\text { Altered morphological dynamics of activated microglia after } \\
\text { induction of status epilepticus (Avignone et al. [45]) }\end{array}$ & $\begin{array}{c}\text { Prairie Ultima } \\
\text { Ti:Sapphire laser (Spectra) } \\
900 \mathrm{~nm} \\
40 \times \text { water immersion objective } \\
\text { (1.00 NA) }\end{array}$ & $\begin{array}{l}\text { Microglia in acute hippocampal slices were imaged to study } \\
\text { how activation affected the dynamics and morphological } \\
\text { properties of these cells. }\end{array}$ \\
\hline $\begin{array}{c}\text { Neuronal hyperactivity recruits microglial processes via } \\
\text { neuronal NMDA receptors and microglial P2Y12 receptors } \\
\text { after status epilepticus (Eyo et al. [46]) }\end{array}$ & $\begin{array}{c}\text { Scientifica Ltd. } \\
\text { Ti:Sapphire laser (Spectra) } \\
800 \mathrm{~nm} \\
40 \times \text { water immersion objective } \\
(0.80 \mathrm{NA})\end{array}$ & $\begin{array}{l}\text { 2PI was used to visualize microglia in mouse hippocampal } \\
\text { slices and on the cortical surface of mouse brains in vivo. }\end{array}$ \\
\hline $\begin{array}{l}\text { Glia-neuron interactions underlie state transitions to } \\
\text { generalized seizures (Verdugo et al. [47]) }\end{array}$ & $\begin{array}{c}\text { Scientifica Ltd. } \\
\text { Ti:Sapphire laser (Spectra) } \\
920 \mathrm{~nm} \\
\begin{array}{c}\text { 16× water immersion objective } \\
(0.80 \mathrm{NA})\end{array}\end{array}$ & $\begin{array}{c}\text { In vivo two-photon calcium imaging was performed to } \\
\text { visualize neuronal and glial cell populations in } \\
\text { transgenic zebrafish. }\end{array}$ \\
\hline $\begin{array}{l}\text { Interactions between microglia and newly formed } \\
\text { hippocampal neurons in physiological and seizure-induced } \\
\text { inflammatory environment (Chugh et al. [48]) }\end{array}$ & $\begin{array}{c}\text { Zeiss } 710 \text { NLOTi:Sapphire laser (Spectra) } \\
760 \mathrm{~nm} \\
63 \times \text { water immersion objective }\end{array}$ & $\begin{array}{l}\text { Labeled neurons and microglia in mouse hippocampal slices } \\
\text { were imaged to study cell interactions. }\end{array}$ \\
\hline
\end{tabular}


Table 3. Astrocytes-data abstraction table catalogues the type of two-photon microscope used and how 2PI was applied in each study within this group of publications.

\begin{tabular}{|c|c|c|}
\hline Title and Authors & Microscope & Application \\
\hline $\begin{array}{l}\text { Rapamycin attenuates acute seizure-induced astrocyte injury in } \\
\text { mice in vivo (Guo et al. [49]) }\end{array}$ & $\begin{array}{c}\text { LSM } 510 \text { Zeiss } \\
\text { Ti:Sapphire laser (Coherent) } \\
900 \mathrm{~nm} \\
40 \times \text { water immersion objective } \\
(0.80 \mathrm{NA})\end{array}$ & $\begin{array}{l}\text { Cortical astrocytes were imaged before and after seizure } \\
\text { induction at various time points in vivo to visualize changes in } \\
\text { number and morphology. }\end{array}$ \\
\hline $\begin{array}{l}\text { Astrocytic atrophy following status epilepticus parallels reduced } \\
\mathrm{Ca}^{2+} \text { activity and impaired synaptic plasticity in the rat } \\
\text { hippocampus (Plata et al. [50]) }\end{array}$ & (Not stated) & $\begin{array}{l}\text { 2PI of astrocytes in the CA1 region of rat hippocampal slices } \\
\text { was performed to monitor status epilepticus-induced changes } \\
\text { in cell morphology. }\end{array}$ \\
\hline $\begin{array}{l}\text { Tight coupling of astrocyte } \mathrm{pH} \text { dynamics to epileptiform activity } \\
\text { revealed by genetically encoded } \mathrm{pH} \text { sensors (Raimondo et al. [51]) }\end{array}$ & $\begin{array}{c}\text { Customized Olympus F300 } \\
\text { Ti:Sapphire laser (Spectra) } \\
810 \mathrm{~nm} \\
40 \times \text { water immersion objective } \\
(0.80 \mathrm{NA})\end{array}$ & $\begin{array}{l}\text { Rat hippocampal slices were imaged and } \mathrm{pH} \text { measurements } \\
\text { were made using three genetically encoded } \mathrm{pH} \text { reporters. }\end{array}$ \\
\hline $\begin{array}{l}\text { Astrocytic glutamate release-induced transient depolarization and } \\
\text { epileptiform discharges in hippocampal CA1 pyramidal neurons } \\
\text { (Kang et al. [52]) }\end{array}$ & $\begin{array}{l}\text { Customized Olympus BX61WI } \\
\text { Ti:Sapphire laser (Spectra) } \\
\quad 820 \mathrm{~nm} \\
60 \times \text { water immersion objective }\end{array}$ & $\begin{array}{l}\text { Exocytosis of vesicles from astrocytes was visualized in rat } \\
\text { hippocampal slices using two-photon calcium imaging. }\end{array}$ \\
\hline $\begin{array}{l}\text { Enhanced astrocytic } \mathrm{Ca}^{2+} \text { signals contribute to neuronal } \\
\text { excitotoxicity after status epilepticus (Ding et al. [54]) }\end{array}$ & $\begin{array}{l}\text { Customized Prairie Ultima } \\
\text { Ti:Sapphire laser (Coherent) } \\
\quad 820 \mathrm{~nm} \\
60 \times \text { water immersion objective }\end{array}$ & $\begin{array}{c}\text { In vivo two-photon calcium imaging and glutamate uncaging } \\
\text { were performed to visualize and activate astrocytes in mice } \\
\text { with status epilepticus. }\end{array}$ \\
\hline $\begin{array}{l}\text { Blocking TNF } \alpha \text {-driven astrocyte purinergic signaling restores } \\
\text { normal synaptic activity during epileptogenesis (Nikolic et al. [55]) }\end{array}$ & $\begin{array}{l}\text { Custom two-photon microscope } \\
920 \mathrm{~nm} \\
40 \times \text { water immersion objective }\end{array}$ & $\begin{array}{l}\text { Two-photon calcium imaging was used to visualize astrocytes } \\
\text { in brain slices of mice with KA-induced seizures. }\end{array}$ \\
\hline $\begin{array}{l}\text { An excitatory loop with astrocytes contributes to drive neurons to } \\
\text { seizure threshold (Gomez-Gonzalo et al. [56]) }\end{array}$ & $\begin{array}{l}\text { Customized Fluoview } 3000 \text { Olympus } \\
\text { Ti:Sapphire laser (Coherent) } \\
830 \mathrm{~nm}\end{array}$ & $\begin{array}{c}\text { Two-photon calcium imaging was used to visualize and } \\
\text { monitor astrocytes, neurons,", and neuropil in isolated guinea } \\
\text { pig brains. }\end{array}$ \\
\hline
\end{tabular}


Table 4. Neurovasculature-data abstraction table catalogues the type of two-photon microscope used and how 2PI was applied in each study within this group of publications.

\begin{tabular}{|c|c|c|}
\hline Title and Authors & Microscope & Application \\
\hline $\begin{array}{l}\text { Astrocytic endfoot } \mathrm{Ca}^{2+} \text { correlates with parenchymal vessel } \\
\text { responses during 4-AP induced epilepsy: An in vivo } \\
\text { two-photon microscopy study (Zhang et al. [57]) }\end{array}$ & $\begin{array}{c}\text { Custom two-photon microscope } \\
\text { Ti:Sapphire laser (Spectra) } \\
800 \mathrm{~nm} \\
20 \times \text { water immersion objective } \\
(1.00 \mathrm{NA})\end{array}$ & $\begin{array}{c}\text { 2PI was used to monitor }\left[\mathrm{Ca}^{2+}\right] \text { in astrocytes and the diameter } \\
\text { of arterioles in the somatosensory cortices of anesthetized mice } \\
\text { during } 4 \text {-AP-induced epilepsy. }\end{array}$ \\
\hline $\begin{array}{l}\text { Spatial landscape of oxygen in and around microvasculature } \\
\text { during epileptic events (Zhang et al. [58]) }\end{array}$ & $\begin{array}{l}\text { Custom two-photon microscope } \\
\text { Ti:Sapphire laser (Spectra) } \\
840 \mathrm{~nm} \\
20 \times \text { water immersion objective }\end{array}$ & $\begin{array}{l}\text { Real-time images of surface vessels were acquired and used to } \\
\text { guide positionings of } \mathrm{PO}_{2} \text { recordings. }\end{array}$ \\
\hline $\begin{array}{l}\text { Preictal and ictal neurovascular and metabolic coupling } \\
\text { surrounding a seizure focus (Zhao et al. [59]) }\end{array}$ & $\begin{array}{l}\text { Custom two-photon microscope } \\
\text { Ti:Sapphire laser (Coherent) } \\
800 \mathrm{~nm} \\
20 \times \text { water immersion objective } \\
(0.95 \mathrm{NA})\end{array}$ & $\begin{array}{l}\text { 2PI was used to visualize in vivo the surface vasculature of rat } \\
\text { cortex and TO measure vessel diameter. }\end{array}$ \\
\hline $\begin{array}{l}\text { Capillary level imaging of local cerebral blood flow in } \\
\text { bicuculline-induced epileptic foci (Hirase et al. [60]) }\end{array}$ & $\begin{array}{c}\text { Custom two-photon microscope } \\
\text { Ti:Sapphire laser (Coherent) } \\
830 \mathrm{~nm} \\
60 \times \text { water immersion objective } \\
(0.90 \mathrm{NA})\end{array}$ & $\begin{array}{l}\text { 2PI was used to visualize the vasculature of the mouse } \\
\text { somatosensory cortex layer II/III in vivo. Imaging data was } \\
\text { used to quantify hemodynamics. }\end{array}$ \\
\hline $\begin{array}{l}\text { Differential contribution of excitatory and inhibitory neurons } \\
\text { in shaping neurovascular coupling in different epileptic neural } \\
\text { states (Lim et al. [61]) }\end{array}$ & $\begin{array}{c}\text { TCS SP8 MP, Leica } \\
\text { Ti:Sapphire laser (Coherent) } \\
680-1080 \mathrm{~nm} \\
10 \times \text { objective }(0.30 \mathrm{NA})\end{array}$ & $\begin{array}{c}\text { In vivo calcium imaging of neural activity was performed in } \\
\text { mice expressing GCaMP6f in excitatory or inhibitory neurons } \\
\text { in the somatosensory cortex to measure changes in } \\
\text { vascular diameter. }\end{array}$ \\
\hline $\begin{array}{l}\text { Shedding light on human cerebral lipofuscin: An explorative } \\
\text { study on identification and quantification (Hakvoort et al. [21]) }\end{array}$ & $\begin{array}{c}\text { Leica TCS SP5 } \\
\text { Ti:Sapphire laser (Coherent) } \\
820 \mathrm{~nm} \\
20 \times \text { objective }\end{array}$ & $\begin{array}{l}\text { Isolated pial arteries from human epileptic patients and } \\
\text { controls were visualized, and the presence of lipofuscin } \\
\text { was quantified. }\end{array}$ \\
\hline
\end{tabular}


Table 5. Neurites-data abstraction table catalogues the type of two-photon microscope used and how 2PI was applied in each study within this group of publications.

\begin{tabular}{|c|c|c|}
\hline Title and Authors & Microscope & Application \\
\hline $\begin{array}{l}\text { Functional properties of granule cells with hilar basal } \\
\text { dendrites in the epileptic dentate gyrus (Kelly \& Beck [62]) }\end{array}$ & $\begin{array}{c}\text { Prairie Ultima } \\
\text { Ti:Sapphire laser (Coherent) } \\
720-740 \mathrm{~nm}\end{array}$ & $\begin{array}{c}\text { Two-photon calcium imaging and glutamate uncaging at } \\
\text { dendrites of dentate granule cells was performed in } \\
\text { hippocampal slices. }\end{array}$ \\
\hline $\begin{array}{l}\text { In vivo imaging of dendritic spines during electrographic } \\
\text { seizures (Rensing et al. [63]) }\end{array}$ & $\begin{array}{c}\text { LSM } 510 \text { Zeiss } \\
\text { Ti:Sapphire laser (Coherent) } \\
900 \mathrm{~nm} \\
40 \times \text { water immersion objective } \\
(0.80 \mathrm{NA})\end{array}$ & $\begin{array}{l}\text { In vivo } 2 \mathrm{PI} \text { was used to visualize dendrites and dendritic } \\
\text { spines of mouse neocortical neurons. }\end{array}$ \\
\hline Brief seizures cause dendritic injury (Guo et al. [64]) & $\begin{array}{c}\text { LSM } 510 \text { Zeiss } \\
\text { Ti:Sapphire laser (Coherent) } \\
900 \mathrm{~nm} \\
40 \times \text { water immersion objective } \\
\text { (0.80 NA) }\end{array}$ & $\begin{array}{l}\text { In vivo 2PI was used to visualize dendrites and dendritic } \\
\text { spines of mouse neocortical neurons. }\end{array}$ \\
\hline $\begin{array}{l}\text { Altered neurotransmitter release, vesicle recycling, and } \\
\text { presynaptic structure in the pilocarpine model of temporal } \\
\text { lobe epilepsy (Upreti et al. [29]) }\end{array}$ & $\begin{array}{l}\text { Customized Olympus BX61WI } \\
\text { Solid-state laser (Spectra) } \\
825 \mathrm{~nm} \\
60 \times \text { water immersion objective } \\
(0.90 \mathrm{NA})\end{array}$ & $\begin{array}{c}\text { Two-photon imaging of vesicular release and presynaptic } \\
\text { machinery in rat and transgenic mouse hippocampal slices } \\
\text { was performed. }\end{array}$ \\
\hline
\end{tabular}

Table 6. Neurometabolism—data abstraction table catalogues the type of two-photon microscope used and how 2PI was applied in each study within this group of publications.

\begin{tabular}{|c|c|c|}
\hline Title and Authors & Microscope & Application \\
\hline $\begin{array}{l}\text { Fluorescence lifetime microscopy of NADH distinguishes } \\
\text { alterations in cerebral metabolism in vivo (Yaseen et al. [65]) }\end{array}$ & $\begin{array}{c}\text { Custom two-photon microscope } \\
\text { Ti:Sapphire laser (Spectra) } \\
740 \mathrm{~nm} \\
10 \times \text { water immersion objective } \\
(1.00 \mathrm{NA})\end{array}$ & $\begin{array}{l}\text { 2PI measurements of reduced NADH fluorescence were } \\
\text { conducted to resolve alterations in cerebral metabolism in a rat } \\
\text { seizure model. }\end{array}$ \\
\hline $\begin{array}{l}\text { Multiphoton fluorescence lifetime imaging of intrinsic } \\
\text { fluorescence in human and rat brain tissue reveals spatially } \\
\text { distinct NADH binding (Chia et al. [66]) }\end{array}$ & $\begin{array}{c}\text { Custom Olympus BX51 } \\
\text { Ti:Sapphire laser (Spectra) } \\
769 \mathrm{~nm} \\
20 \times \text { water immersion objective } \\
(0.95 \mathrm{NA})\end{array}$ & $\begin{array}{l}\text { NADH fluorescence images were collected in control and } \\
\text { epileptic rat tissue. Use of a custom image-processing } \\
\text { algorithm indicated differences in metabolic capacities. }\end{array}$ \\
\hline
\end{tabular}




\section{Results}

The search string resulted in 83 hits in PubMed, 90 hits in JSTOR, and 153 hits in Embase. Ultimately, 38 papers from this collection were selected for inclusion in this literature review. The complete search process is illustrated in Figure 1. A lists of all the studies are included in Supplementary Materials S1.

\subsection{Study Characteristics}

The papers included in this review span sixteen years, with the earliest paper published in 2004 and the most recent in 2020. Most studies used rodent models, except for Cozzolino et al. [39], and Verdugo et al. [47], who both used zebrafish models, while Kerekes et al. [40], Chia et al. [66], and Hakvoort et al. [21] examined human brain tissue. Twenty-three studies used mouse models [31-34,36,37,41,42,45,46,48,49,53-55,58,60,61,63,64], seven used rat models [50-52,59,62,65,66], three used both rat and mouse models [29,35,38], and one used a guinea pig model [56]. In addition, fourteen of the studies applied 2PI to visualize ex vivo cells in brain slices $[21,29,34,35,38,40-42,45,48,50-52,55,56,62,66]$, while seventeen studies employed 2PI in vivo [31-33,36,37,39,43,47,49,57-61,63-65]. Three studies utilized a combination of in vivo and ex vivo approaches $[44,46,53]$. In vivo 2 PI was performed by a small craniotomy in the animal, allowing direct access to the brain for visualization and uncaging. The animals were lightly or fully sedated during experiments. For experimental seizure-induction, different pharmacological agents were used across the studies, including kainic acid (KA), 4-aminopyridine, pilocarpine, and bicuculline methiodide. Note, however, that in the studies conducted by Hirase et al. [60] and Petrucco et al. [36], the effects of interictal epileptiform activity were investigated by infusion of bicuculline methochloride, inducing focal interictal spiking. Finally, nearly all studies employed an additional electrophysiological recording technique (local field potential recording, patch-clamp recording, or electroencephalography (EEG)) to confirm the induction of epileptiform activity and to correlate imaging data (structural) with electrophysiological data (functional) for temporal precision.

\subsection{Findings}

\subsubsection{Epileptic Network Propagation}

In epilepsy, there is a disbalance between excitation and inhibition. Neurons become pathologically hyperexcitable and are therefore capable of repetitive generation of action potentials. When a significant number of neurons fire excessively in a hyper-synchronized manner, epileptic seizures manifest. The studies within this group evaluated functional changes that resulted from epileptiform activity. 2PI allowed for two-photon calcium imaging (calcium concentrations $\left[\mathrm{Ca}^{2+}\right]$ ) and visualization of neurons within the local seizure onset zone in and ex vivo. In the majority of these studies, the fluorescent indicator GCaMP5G was used. This imaging allowed for mapping of patterns of neuronal recruitment and seizure propagation, sometimes in combination with electrographic recordings to verify 2 PI findings [35-37].

Wenzel et al. [32] used 2PI visualization of neurons and interneurons $\left[\mathrm{Ca}^{2+}\right]$ to find that, during focal seizure propagation, neuronal populations are recruited in a saltatory fashion. However, despite consistent recruitment pathways, propagating seizures showed temporal variability dependent on local interneuron GABAergic inhibition. This finding was supported by Cammarota et al. [35], who used 2PI $\left[\mathrm{Ca}^{2+}\right]$ signal images to record inhibitory effects in pyramidal neurons and found that they correlated with inhibitory interneuron $\left[\mathrm{Ca}^{2+}\right]$ during ictal discharges. They also described firing impairments of inhibitory interneurons preceding ictal discharges in neighboring pyramidal neurons. Similarly, Liou et al. [31] and Lillis et al. [41] also reported that focal seizures were associated with heterogeneous inhibitory $\left[\mathrm{Ca}^{2+}\right]$ interneuron activity outside the seizure focus. Furthermore, Kerekes et al. [40] combined two-photon calcium imaging and glutamate uncaging with electrophysiological measurements in neocortical slices of epileptic patients. The dynamics of neuronal $\left[\mathrm{Ca}^{2+}\right]$ activity in human tissue follow similar patterns to those 
in experimental animal models, and combining electrophysiological recording techniques with $2 \mathrm{PI}$ can be used to probe the functional and structural properties of human cortex in pathological conditions.

Cozzolino et al. [39] cross-correlated $\left[\mathrm{Ca}^{2+}\right]$ events to develop a spatial recruitment map of neuronal population during seizures in zebrafish. The cerebellum was found to be the main source of epileptiform transients. In addition, Petrucco et al. [36] and Muldoon et al. [37] investigated the effects of inducing interictal activity in experimental rodent models. Petrucco et al. [36] demonstrated that interictal spiking resulted in widespread $\left[\mathrm{Ca}^{2+}\right]$ alterations. These alterations in $\left[\mathrm{Ca}^{2+}\right]$, in combination with electrophysiological registered field potential disruptions, were even found in the contralateral hemisphere as well.

By using 2PI visualization of GCaMP5G, Muldoon et al. [37] showed that GABAergic neurons are preferentially recruited (as opposed to glutamatergic) during interictal activity in the cornu ammonis 1 (CA1) region of the epileptic mouse hippocampus. Finally, Müller et al. [38] demonstrated the applicability of a $\mathrm{K}^{+}$-sensitive fluoroionophore FI3 to efficiently stain neurons and intra- and extracellular $\mathrm{K}^{+}$, allowing for $2 \mathrm{PI}$ visualization of $\mathrm{K}^{+}$dynamics during seizure activity.

\subsubsection{Microglia}

Microglia are resident macrophage cells, acting as the first and main forms of active immune defense of the central nervous system. The application of 2PI to microgliafocused epilepsy research demonstrates structural and functional changes of microglia in pathological conditions. Changes in cell morphology and activity that result from experimental seizure induction were predominantly assessed. 2PI also enabled assessment of changes in microglial proliferation, translocation, as well as the frequency and nature of specific microglial-neuron interactions.

Feng et al. [42] and Avignone et al. [45] observed that seizure-activated microglia had significantly larger cell bodies, with fewer and shorter processes compared to inactivated microglia in control animals (see Figure 2). In terms of activity, seizures resulted in significant microglial proliferation in the hippocampus. Pharmacological inhibition of microglial proliferation could also be visualized with 2PI, and this correlated with the attenuation of neuronal death during seizures, thereby suggesting a neurotoxic role of microglia during epileptic activity.

A

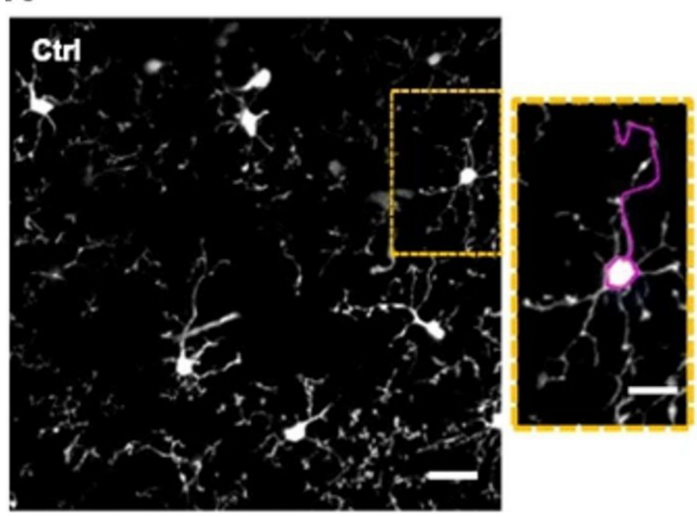

B

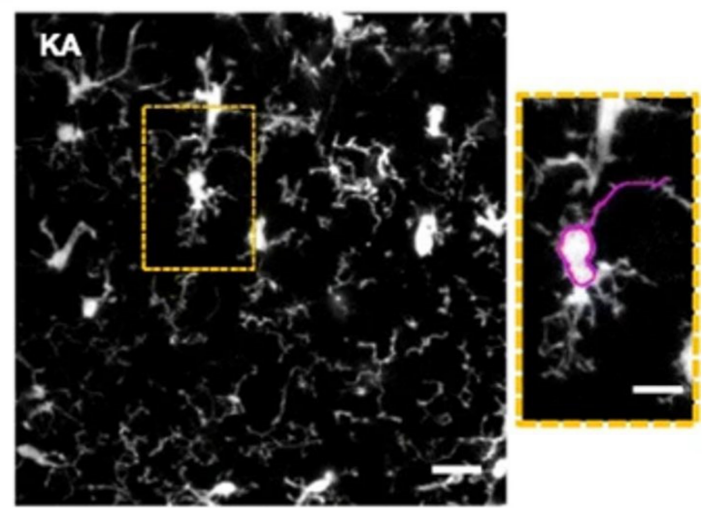

Figure 2. Two-photon images of microglial cells obtained in control mice (A) and KA-induced status epilepticus mice (B) depicting significantly different cell morphologies. Cell body outlines were drawn manually to determine cell sizes. After treatment with KA, microglial cells are significantly larger and have significantly shorter processes (consider the cell depicted in the inset images). Scale bars: $10 \mu \mathrm{m}$ (main images) and $6 \mu \mathrm{m}$ (inset images). Adapted from "Altered morphological dynamics of activated microglia after induction of status epilepticus" (Avignone et al., Journal of Neuroinflammation, 2015 [45]). This figure has been modified. Creative Commons license: https:/ / creativecommons.org/licenses/by/4.0/ (accessed on 17 November 2020). 
Eyo et al. [43] and Avignone et al. [45] visualized using 2PI that microglial translocation and rearrangement significantly increase during epileptiform activity. In fact, Avignone et al. [45] described increased translocation activity of microglia in pathological conditions. In P2Y12-deficient mice, this microglial translocation was not observed, though these mice exhibited worsened seizure phenotypes, which is indicative of a neuroprotective role of microglia in epileptic conditions $[43,46]$.

Furthermore, Eyo et al. [44] visualized a specific type of microglia-neuron interaction, namely microglial process convergence events (MPCs). They reported that the frequency of these MPCs dramatically increased upon extracellular calcium reduction (also visualized with 2PI), leading to epileptiform activity. A decrease in the frequency of MPCs in fractalkine-deficient slices were seen, corresponding with increased seizure phenotypes. These findings identified fractalkine signaling as a regulator of neuroprotective microglianeuron interactions during epileptiform activity. Chugh et al. [48] also described alterations to specific microglia-neuron interactions in synaptic integration. 2PI was able to visualize that, under physiological conditions, microglia interacted more with distal dendrites of neurons, whereas following status epilepticus, microglia interacted more strongly with proximal dendrites.

Finally, Verdugo et al. [47] described differences in the activities of neural and glial networks during the transition from preictal to seizure states. Using a zebrafish model of epilepsy, it was demonstrated that glial networks are highly active and strongly synchronous preictally. However, in generalized seizure states, neural activity and connectivity abruptly increased, and this was associated with alterations in interactions between neurons and glial cells.

\subsubsection{Astrocytes}

Astrocytes are characteristic star-shaped glial cells that, amongst other functions, support and maintain neurons and the blood-brain barrier. 2PI has been applied to study the properties of these cells in epileptic conditions. Specifically, eight papers investigate the changes in cell morphology and activity that result from experimental seizure induction. Within these studies, 2PI was used to visualize astrocytes at different time points during seizures in vivo and ex vivo. In terms of morphological changes, astrocytic vacuolization and decreases in astrocytic cell sizes were observed, shown in Figure 3 [49]. Furthermore, a significant decrease in the number of astrocytic branches was noted within the CA1 region of the hippocampus after seizures [50].

2PI was also employed to monitor $\left[\mathrm{Ca}^{2+}\right]$ signaling of astrocytes. Five studies [52-56] highlighted that altered $\mathrm{Ca}^{2+}$ signaling of astrocytes was correlated with the onset and progression of epileptic seizures. Tian et al. [53] performed an uncaging experiment in which $\left[\mathrm{Ca}^{2+}\right]$ was actively altered, resulting in glutamate release (confirmed by chromatography analysis of glutamate), leading to local depolarization events and epileptiform activity. Tian et al. also used 2PI to visualize the interference of astrocytic $\mathrm{Ca}^{2+}$ signaling by several anti-epileptic drugs, which reduced the ability of astrocytes to release gliotransmitters such as glutamate. Ding et al. [54] observed that enhanced astrocytic $\mathrm{Ca}^{2+}$ signaling, in addition to corresponding with seizure activity, also correlates strongly with neuronal death. To determine whether astrocytes directly contribute to neuronal death, antagonists that inhibit gliotransmission were administered and these provided significant neuronal protection. Similarly, Nikolic et al. [55] demonstrated that ictal discharges are strongly associated with increases in astrocytic $\mathrm{Ca}^{2+}$ signaling and subsequent release of tumor necrosis factor $\alpha$, a cytokine involved in the regulation of astrocytic glutamate release. 

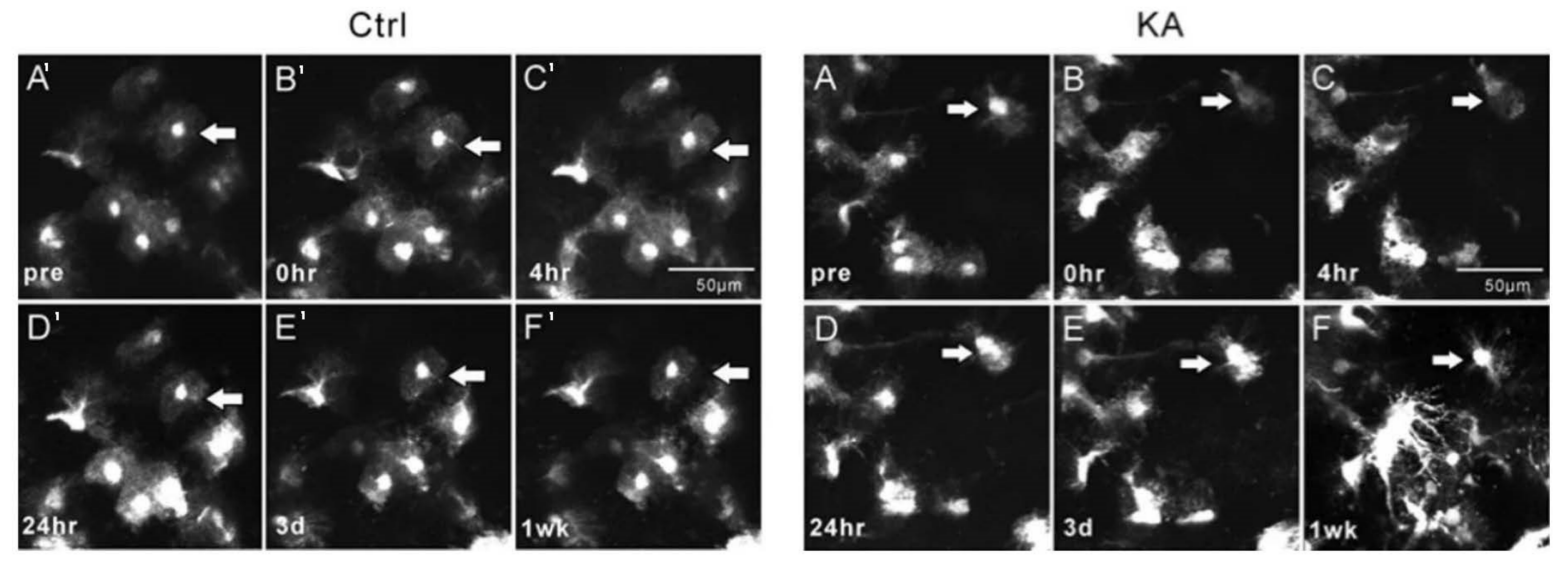

Figure 3. In vivo two-photon images of astrocytes in control mice (Ctrl, left) and KA-induced status epilepticus mice (KA, right) at several time points (A: baseline, B-F: corresponding time from induction). The images depict seizureinduced changes in astrocyte morphology (vacuolization and decreased average cell sizes). The white arrows show tracked astrocytes. Under normal conditions (Ctrl, left), astrocytes have a consistent appearance and thin processes, with no significant changes in fluorescence, number, or cell size occurring over a one-week period (Ctrl, $\left.\mathbf{A}^{\prime}-\mathrm{F}^{\prime}\right)$. On the other hand, KA-induced seizures (KA, right) resulted in cell vacuolization and astrogliosis at the one-week time point (KA, A-F). In addition, astrocytes underwent a reduction in average cell size and astrocytic processes appeared more prominent and extensive (KA, F). Scale bars: $50 \mu \mathrm{m}$. Adapted from "Rapamycin attenuates acute seizure-induced astrocyte injury in mice in vivo" (Guo et al., Scientific Reports, 2017 [49]). This figure has been modified. Creative Commons license: https:/ / creativecommons.org/licenses/by/4.0/ (accessed on 17 November 2020).

\subsubsection{Neurovasculature}

Neurovascular abnormalities in epilepsy include changes in blood flow due to dysfunctional neurovascular coupling, increased permeability of the blood-brain barrier, oxidative stress, and a more recent focus on disbalances in angiogenesis $[67,68]$. We found six studies evaluating pathological activity-induced changes in the neurovasculature, visualizing the neurovasculature and vascular responses to ictal or interictal activity [60].

Zhang et al. in 2017 [58] were able to quantify oxygen partial pressure in epileptic foci with 2PI, showing a decreased partial oxygen pressure surrounding small arterioles during epileptic activity. Zhang et al. in 2019 [57] also correlated observed vessel responses with astrocytic $\mathrm{Ca}^{2+}$ activity. Increases in $\left[\mathrm{Ca}^{2+}\right]$ were associated with vasodilation at the focus during ictal events, whereas in distal areas, increases in $\left[\mathrm{Ca}^{2+}\right]$ were associated with vasoconstriction at the onset of a seizure and vasodilation at a later point during seizures. $2 \mathrm{PI}$ was of notable value to these studies, as it allowed for high-resolution visualization of subtle processes, such as vasoconstriction and vasodilation. Additionally, Hakvoort et al. [21] were able to accurately monitor the build-up of lipofuscin in pial arteries of human epileptic tissue using three-dimensional two-photon fluorescence lifetime microscopy. The autofluorescent lipofuscin, an end-product of oxidative stress, was identified and quantified, indicating a role of oxidative stress in epilepsy.

Hirase et al. [60] used 2PI to visualize and quantify the flow of red blood cells in capillaries in vivo, yielding 2PI measurements of blood flow. They reported that induced interictal activity resulted in increased blood flow to the interictal focus relative to distant regions. Zhao et al. [59] described a novel phenomenon found using 2PI, wherein ictal events were preceded by vasoconstriction of vessels in regions distal from the focus. In response to seizures, however, vessels were found to dilate, with increasing degrees of dilation when more proximal to the focus. In terms of temporal characteristics, vasodilation in the focus occurred almost immediately after seizure onset whereas preictal vasoconstriction of vessels in distal regions occurred $5.3 \pm 0.5 \mathrm{~s}$ before seizure onset (see Figure 4). Preictal vasoconstriction was also observed in the study by Lim et al. [61], and this was found to be correlated with increased excitatory and reduced inhibitory neuronal activity levels, as shown with $\left[\mathrm{Ca}^{2+}\right] 2 \mathrm{PI}$. 

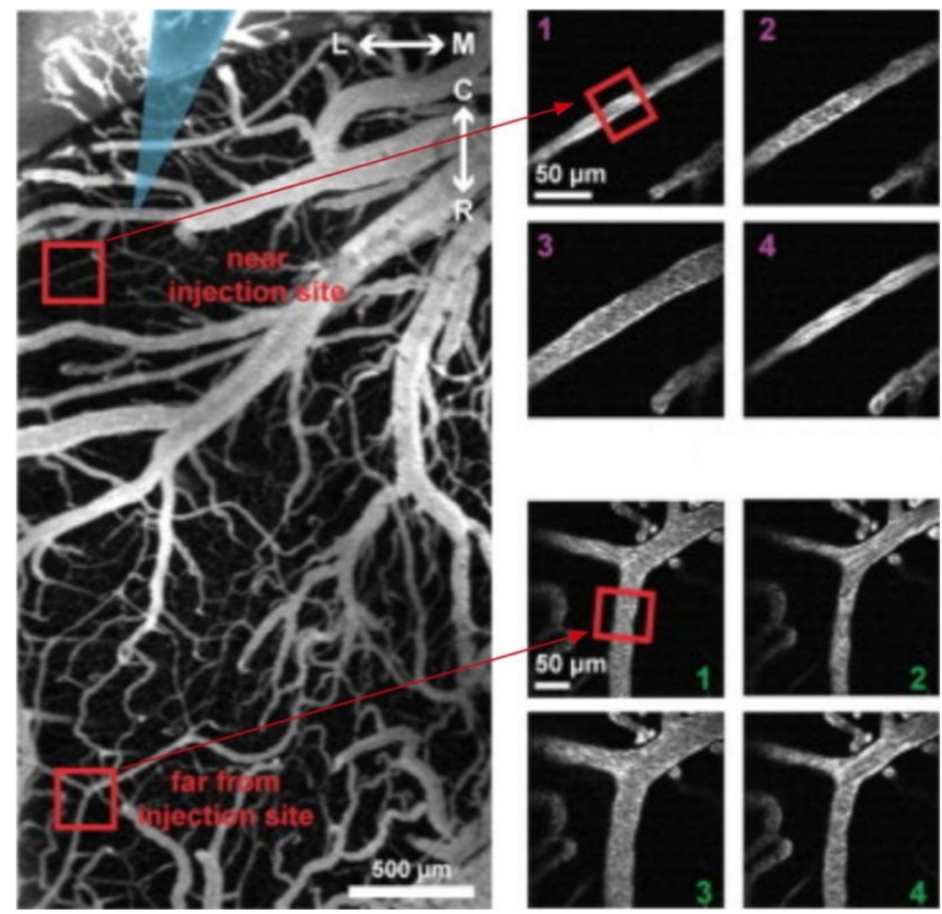

Figure 4. In vivo two-photon images of rat surface vasculature depicting vessel responses to 4-APinduced ictal activity at different time points (1: injection, 2: seizure onset, 3: maximum dilation, 4: restoration to baseline). The upper inset images demonstrate vasodilation near the seizure focus at the time of seizure onset (2), subsequent propagation (3) and restoration to baseline (4). The lower inset images demonstrate vasoconstriction away from the seizure focus at onset (2), followed by dilation at a later point (3), before restoring to baseline (4). Scale bars: $500 \mu \mathrm{m}$ (main image) and $50 \mu \mathrm{m}$ (inset images). Adapted from "Preictal and ictal neurovascular and metabolic coupling surrounding a seizure focus" (Zhao et al., The Journal of Neuroscience, 2011 [59]). This figure has been modified. Creative Commons license: https://creativecommons.org/licenses/by/4.0/ (accessed on 20 November 2020).

\subsubsection{Neurites}

Neurites refer to projections from the cell bodies of neurons, either dendrites or axons. Dendrites are branched protoplasmic extensions of nerve cells that propagate the electrochemical impulses received from other neural cells, while axons propagate electrical impulses to other neurons. We identified four papers evaluating the effects of seizures on dendritic and axonal structure. Specifically, spine loss, swelling, abnormal development, and vesicular release were analyzed.

By visualizing dendrites of neocortical neurons in vivo, Rensing et al. [63] demonstrated that minor seizures produced minimal effects on dendritic spines of neocortical neurons whereas severe seizures were associated with significant spine loss as well as dendritic swelling. In contrast, Guo et al. [64] observed that the degree of seizure-induced dendritic injury was related to seizure duration and that even brief seizures were capable of inducing dendritic beading and spine loss. Additionally, it was found that dendritic injury caused by minor seizures usually recovered within two weeks whereas dendritic injury caused by severe seizures recovered only partially.

Kelly and Beck [62] investigated the properties of hilar basal dendrites (HBDs) using glutamate uncaging at dendrites of granule cells in rat hippocampal slices. In temporal lobe epilepsy, granule cells in the dentate gyrus can develop abnormally and can possess an $\mathrm{HBD}$, promoting pathologically seizure propagation.

Finally, Upreti et al. [29] visualized the effects of seizures on presynaptic machinery, namely mossy fiber axons and vesicular release. The mossy fiber pathway consists of unmyelinated axons projecting from the hippocampal dentate gyrus. Following pilocarpine- 
induced status epilepticus, significant increases in mossy fiber axon sizes and faster rates of vesicular release were observed, suggesting altered structural and functional properties due to seizure activity.

\subsubsection{Neurometabolism}

Nicotinamide adenine dinucleotide (NADH) is an intrinsically fluorescent cofactor central to cellular metabolism. Two-photon fluorescence lifetime imaging (2P-FLIM) of NADH can therefore be used to monitor metabolism in cellular populations. Chia et al. [66] used 2P-FLIM to visualize rat hippocampal slices of epileptic animals and controls and demonstrated that NADH concentrations were significantly lower in brain tissue from epileptic rats than in brain tissue from controls. This result may be attributed to a "reduced metabolic potential of the neurons and astrocytes or an overall loss of neurons".

More recently, Yaseen et al. [65] used NADH fluorescence in an in vivo rat seizure model to resolve alterations in cerebral metabolism. The imaging data were used to generate classification models, which consistently predicted that prolonged seizure activity resulted in impairments of the electron transport chain due to a discrepancy between metabolic demand for oxygen and supply.

\section{Discussion}

Our review includes 38 studies on the application of 2PI in epilepsy research. We observed the application of 2PI in a range of pathophysiological mechanisms underlying epilepsy. 2PI has demonstrated its value by shedding more light on a large spectrum of functional and morphological abnormalities that are associated with epilepsy. It allowed for the direct visualization of neurons, astrocytes, microglia, and neurites, revealing morphological changes. Alterations in biological compounds such as $\left[\mathrm{Ca}^{2+}\right]$, glutamate, and NADH indicate functional changes. Furthermore, visualization of blood vessels, vasomotor responses, blood flow alterations, and partial oxygen pressure revealed a variety of neurovascular changes associated with epileptic activity. Since current research on the pathophysiology of epilepsy focuses increasingly on neurovascular alterations and oxidative stress, the application of 2PI in this field is emphasized in our discussion. However, we start this discussion with a more detailed description of the specific features and potential of 2PI in general.

\subsection{Two-Photon Imaging}

Novel advances in unraveling the pathomechanisms associated with epilepsy described in this review have benefitted greatly from the advent and development of 2PI as an imaging technique. This subsection describes specific features of 2PI and how these features were utilized within studies included in this review.

2PI enables high-resolution deep tissue imaging of vascular structures, neuronal cells, and fluorophores, with limited background signal [1], and is suitable for molecular imaging of living tissues or in live animals. This feature was fully taken advantage of in some of the studies included in the present review. For example, three studies $[57,59,60]$ were able to visualize subtle changes in the microvasculature (namely vasodilation and vasoconstriction) that accompany epileptiform activity. In vivo 2PI can be used to quantify hemodynamics and vascular responses after epileptiform activity. Additionally, 2PI was even employed to measure capillary flow during epileptiform activity [60], and visualization of neurons, microglia, astrocytes, and neurites revealed morphological changes accompanying seizures. As a result of these specific features, 2PI allowed for the identification of functional and structural alterations in epilepsy, which have not been described previously. In these in vivo instances, using confocal laser scanning microscopy would have likely been inadequate, as comparatively, 2PI significantly reduces photobleaching, increases cell viability, and allows for deeper tissue penetration [69]. Furthermore, it has been reported that, when imaging neuronal cells specifically, single-photon microscopy suffers from increased interference by neuropil and decreased signal-to-noise ratio compared to 2PI [70]. 
2PI is particularly well-suited for uncaging experiments, which involves the use of light to artificially activate biological compounds, such as glutamate or calcium, and therefore to increase their concentrations in small focal volumes [71]. Due to the inherent nonlinearity of the two-photon system, $2 \mathrm{PI}$ is more suitable for uncaging than conventional single-photon excitation [72]. Two-photon uncaging produces excited states exactly as UV excitation does while also overcoming major limitations when probing biological tissue, such as spatial resolution, tissue penetration, and toxicity [73]. Two-photon uncaging is of special interest in epilepsy research, as imbalances between excitatory (glutamatergic) and inhibitory (GABAergic) neurotransmission have been implicated in the pathogenesis of the disorder $[27,28,74]$. Uncaging is used in four of the studies included in this review. Kelly and Beck [62] performed glutamate uncaging in dendrites of granule cells, whereas Tian et al. [53] and Ding et al. [54] used uncaging to trigger astrocytic $\left[\mathrm{Ca}^{2+}\right]$ signaling and glutamatergic gliotransmission. The findings presented in the latter two publications were groundbreaking and paved the way for subsequent research into the role of astrocytes and astrocytic transformation in epilepsy. As such, the use of 2PI directly and unequivocally contributed to our understanding of a novel aspect of epilepsy [72].

2P-FLIM was used in both papers on neurometabolism. Fluorescence decay profiles of intrinsic NADH were measured in vivo surrounding seizures and induced metabolic inhibition. This led to imaging and confirmation of the hypothesis that NADH binding and metabolic capacity are significantly impaired following focal seizure activity $[65,66]$. One paper successfully applied 2P-FLIM to image intrinsic NADH in living human brain tissue [66]. Furthermore, 2P-FLIM was used to identify the lifetime of substances, such as $\left[\mathrm{Ca}^{2+}\right]$ and $\mathrm{pO}_{2}$, providing interesting information on quantified fluctuations of concentration over time $[57,58]$ while also allowing for identification and quantification of lipofuscin in the cerebral vasculature [21]. Finally, in 20 of the 38 included studies, 2PI was used to image animal brains in vivo. With the surgical implantation of a cranial window in the skull of an animal following anesthesia administration; imaging experiments can subsequently be performed by focusing the excitation laser through this cranial window. In vivo animal models are more representative of the human epileptic state compared to ex vivo models, let alone histological imaging on thin sections. The findings from in vivo 2PI studies are significant because high-resolution information can be obtained, which is not possible with current clinical techniques, and is therefore better translatable. To improve translatability, further imaging of human cerebral tissue is warranted. To date, only three studies included human brain tissue $[21,40,66]$.

\subsection{Two-Photon Imaging in Epilepsy Research}

The papers included in this review described several interesting and sometimes novel findings in the field of epilepsy research. The relevance of pathological hyperexcitability, whereby individual neurons become increasingly capable of generating repeated action potentials, is a widely recognized phenomenon in epilepsy [75,76]. It is thought this pathological hyperexcitability arises due to inhibitory control failure [77]. We found that several studies in this review applied 2PI to shed more light on this process. For example, the described "inhibitory model" of seizure propagation, wherein the collapse of local inhibition leads to neuronal recruitment during ictal discharges, was suggested by the findings of multiple included studies $[31,32,35,39,41]$. In these studies, 2PI allowed monitoring of $\left[\mathrm{Ca}^{2+}\right]$ of neurons and interneurons, revealing their activity. In addition, the interactions between glial cells and neurons were revealed through 2PI calcium imaging, underlining the importance of the glial environment in epileptic states. Additionally, we found that morphological changes to dendrites and axons can lead to dysfunction, possibly contributing to pathological hyperactivity [62]. Another characteristic feature of epilepsy is interictal spiking, which refers to abnormal neuronal discharges between seizures. Previous reports have addressed interictal spiking [78]; however, 2PI was needed to demonstrate the widespread impact of interictal spiking on interconnected regions of the brain by visualizing $\left[\mathrm{Ca}^{2+}\right]$. This finding suggested a prominent role of interictal 
spiking in epilepsy [36,37]. However, the exact mechanisms responsible for the emergence of spontaneous interictal activity remain unknown. Interestingly, 2PI calcium imaging of neuronal activity in the in vitro human neocortex seemed viable and comparable to patterns in experimental animal models.

Important morphological changes in microglia, astrocytes, and neurites due to epileptiform activity were revealed in studies that applied 2PI. Using 2PI, changes in the mean sizes of cell bodies and the quantification of microglial processes before and after seizureinduction were recorded $[42,45]$. Such findings have not been reported previously. Alterations in the interactions of microglia and neurons in neuronal integration were described in epileptic states. Interestingly, microglia were identified to play a neurotoxic as well as a neuroprotective role in epileptic conditions, and the exact significance of this finding has yet to be explored. Furthermore, astrocytic $\left[\mathrm{Ca}^{2+}\right]$ signaling and subsequent glutamate release was identified as a key process contributing to the development and progression of ictal discharges. These findings are highly relevant, as astrocytic $\left[\mathrm{Ca}^{2+}\right]$ modulation provides a novel mechanism for seizure development and progression. This in turn indicates that astrocytes are capable of playing an active, dynamic role in modulating brain function $[55,79]$. This led to the understanding that the role of astrocytes goes far beyond its previously delineated supportive role in maintaining local structures and metabolism. This finding has revolutionized our understanding of epilepsy and has resulted in the concept that "astrocytic transformation" plays a major role in its pathophysiology [80].

Given the recent change in epilepsy research from a neuronal-centered toward a vascular-centered concept of epileptogenesis [9-12], neurovascular alterations in epilepsy are of major interest. By using 2PI, changes in blood flow were visualized, with different states of vasoconstriction and vasodilation surrounding the epileptogenic focus [59-61]. Preictal vasoconstriction was found to be correlated with increased excitatory and reduced inhibitory neuronal activity levels [61]. These findings indicate that excitatory and inhibitory neurons affect surrounding neurons during epileptiform activity leading to dysfunctional local inhibition, which is supportive of the aforementioned "inhibitory model" of seizure propagation. Furthermore, the finding that astrocytic $\left[\mathrm{Ca}^{2+}\right]$ corresponds with vessel responses [57] also suggests that astrocytes may play an active role in mediating changes in the neurovasculature in epilepsy.

Lastly, 2PI was employed to detect concentrations of NADH, an important cofactor central to metabolism, to identify neurometabolic alterations $[65,66]$. NADH 2PI fluorescence revealed prolonged seizure activity resulting in impairments of the electron transport chain as a consequence of inadequate oxygen supply, suggesting long-term altered metabolic capacity of neural tissue in epilepsy, possibly contributing further to pathological processes.

\subsection{Oxidative Stress}

Oxidative stress plays an important pathophysiological role in intracellular mechanisms in all of the aforementioned cells and processes [68,81,82]. Most of the involved proteins and molecules in oxidative stress are difficult to assess due to their short lifespan and rapid reactivity with redox state regulating components [83]. Hence, a robust analysis of the role of oxidative stress in epilepsy pathomechanisms using 2PI requires assessment of non-degradable fluorescent or autofluorescent composites. In this regard, lipofuscin forms an interesting end-product of oxidative stress as it is a nondegradable substance with strong and specific autofluorescent properties [84,85]. It is most commonly found in the cytoplasm of cells with a low rate of mitosis, such as neurons [86]. Its aggregation is associated with the pathophysiology of epilepsy as well as with neurodegenerative disorders [22,87]. We recently associated lipofuscin with the pathophysiology of epilepsy using 2PI in vascular and tissue samples of epilepsy patients that were harvested following surgical resection of epileptic brain regions [21]. We found that lipofuscin is present in the brain's pial arterial wall and neocortical parenchyma in young epilepsy patients and age-matched controls. In the three-dimensional reconstruction of the 2PI image stack, the particles appeared to be mainly located within the adventitia and to a lesser extent in the 
tunica media (shown in Figure 5) [21]. Further quantitative analysis of lipofuscin particles suggested that progressive accumulation of lipofuscin in the vascular wall may be related to the pathophysiology of epilepsy.

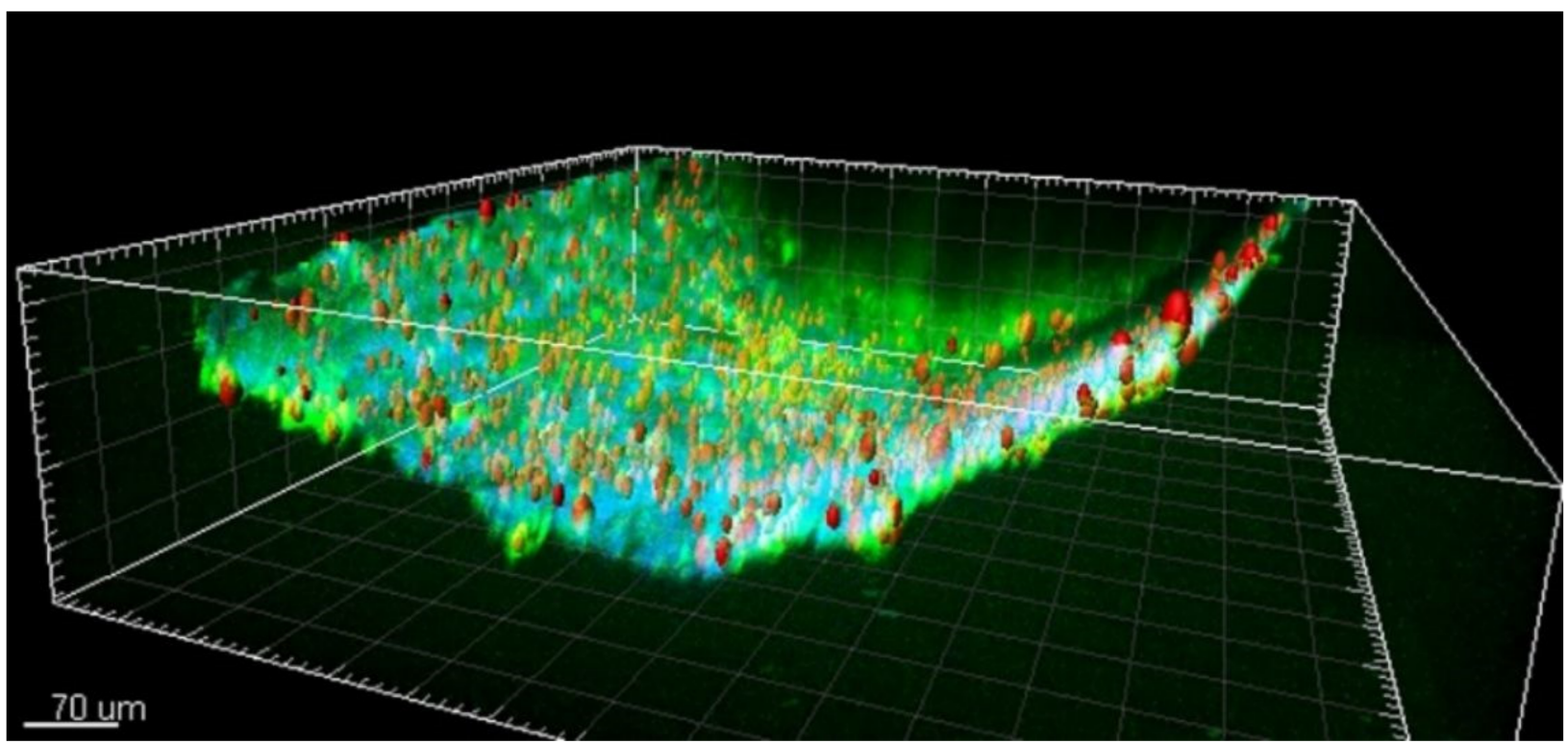

Figure 5. A representative two-photon 3D reconstruction image of lipofuscin autofluorescent particles. Scalebar: $70 \mu \mathrm{m}$. Adapted from "Shedding light on human cerebral lipofuscin: An explorative study on identification and quantification" (Hakvoort et al., Journal of Comparative Neurology, 2020 [21]). A license to reuse this figure from its original source was acquired through RightsLink. (Reprinted with permission from ref. [21]. Copyright 2020 IEEE).

Previous studies also reported on lipofuscin aggregation in association with human epilepsy. Liu et al. [88] described excessive lipofuscin accumulation within dysmorphic neurons in young adult patients with focal frontal lobe epilepsy. Furthermore, lipofuscin has been found in mesial temporal lobe structures of epilepsy patients. Here, oxidative damage and neuronal degeneration induced by seizures seemed to contribute to the formation of lipofuscin in the hippocampus of kainate-treated mouse epilepsy models [89]. In patients with temporal lobe epilepsy, the hippocampal antioxidative system was upregulated [90]. This finding was most pronounced in patients with hippocampal sclerosis [90]. Another article reported on the identification of lipofuscin granules within the entorhinal regions and amygdala of epileptic tissue [91].

These findings provide a basis for understanding the potential involvement of oxidative alterations in the pathophysiology of epilepsy. Analysis of lipofuscin could be a new method to detect and quantify oxidative stress. Using 2PI, lipofuscin is recognized relatively easily based on its specific autofluorescent and lifetime characteristics [21]. Furthermore, the finding of lipofuscin accumulation within the vascular wall in addition to lipofuscin-accumulation in post-mitotic cells such as neurons warrants further assessment.

\subsection{Zebrafish Models of Epilepsy}

While the majority of research in this area has so far been conducted using rodent models, zebrafish models of epilepsy are increasingly adopted. Two studies in this review used zebrafish models of epilepsy and 2PI $[39,47]$. Zebrafish are said to represent an excellent compromise between system complexity and experimental accessibility [39].

A recent study demonstrated that brain trauma can induce epileptogenesis and seizures associated with inflammation and blood-brain barrier dysfunction in zebrafish, which resembles pathophysiological processes in human posttraumatic epilepsy [92]. Additionally, the cerebral vasculature of zebrafish is morphologically and physiologically similar to humans and can readily be genetically manipulated [93]. These properties make 
zebrafish models suitable for epilepsy research, especially considering the recent shift towards studying epilepsy as a vascular disorder.

The use of zebrafish models of epilepsy is rapidly increasing, and recent studies conducted using these models make a good case for their potential [94]. Combining their use with 2PI is an exciting prospect that may aid our understanding of the different aspects of epilepsy.

\subsection{Limitations}

Despite a systematic and thoughtful search strategy, we may have missed some papers worthy of inclusion in this review. As all papers focused on their results, it was often challenging to extract which results were found specifically using 2PI. Discrepancies in methodologies such as the animal models utilized, seizure-induction methods, seizure durations and magnitudes, and other variables limit the comparability of the included studies. In fact, there are some instances of conflicting observations. Epilepsy is a syndrome referring to a group of distinct neurological disorders wherein epileptic seizures are a common symptom. Therefore, there can be significant variation and heterogeneity in terms clinical manifestation as well as the underlying biological and pathophysiological mechanisms and pathways responsible.

Additionally, animal models cannot fully replicate human epilepsy. While pharmacological agents such as 4-AP, kainic acid, and pilocarpine are capable of generating seizures, these seizure models are not representative of human epilepsy as a whole. Human epilepsy is characterized by several complex processes, including epileptogenesis and spontaneous interictal activity, which cannot be suitably replicated experimentally. It is also noteworthy that the use of anesthesia in in vivo 2PI experiments of live animals may represent a confounding variable by exerting unintended effects. These factors affect the translatability of findings presented in such studies. Hence, more research using human tissue is warranted.

With regard to the application of 2PI in epilepsy research, the surgical implantation of cranial windows for in vivo $2 \mathrm{PI}$ experiments can present some challenges. It has been reported that image quality may be diminished by craniotomy closure due to wound healing and inflammatory responses [95]. However, this is not a major limitation as these effects can be nullified by employing sterile surgical techniques and by minimizing trauma [95]. Although 2PI allows for deeper tissue penetration compared to single-photon microscopy, it is still limited to a depth of $2 \mathrm{~mm}$ into the brain. Beyond this depth, the scattering effects reduce image quality significantly. However, advances in the development of fiber-opticbased two-photon endomicroscopes potentially allow for in vivo probing of deep brain structures in experimental contexts [96]. Another limitation of the application of 2PI in epilepsy research relates to the use of calcium-sensitive dyes to stain and subsequently visualize cells. Overexpression of such calcium indicators may cause unintended perturbations of baseline calcium levels. In fact, it has been reported that transgenic mice expressing the calcium indicator GCaMP6 can undergo modulations in electrical activity over large regions of cortex. These effects have been documented in mice of either sex across multiple laboratories [97].

\subsection{Future Perspectives}

Currently, drug-resistant epilepsy is still awaiting new treatment options that may be aimed at as-of-yet unraveled mechanisms. The advantages of 2PI as demonstrated in this review have paved the way to visualize novel and specific processes associated with epilepsy. As such, the additional value of 2PI lies in the potential to find novel targets for antiepileptic therapies in the quest for seizure prevention. In this regard, studying the effects of epilepsy and anti-epileptic drugs on electrolytes such as $\mathrm{Ca}^{2+}$ and neurotransmitters such as glutamate and GABA have been shown to be highly relevant. Future studies that, for example, assess the application of $\mathrm{K}^{+}$-sensitive fluoroionophore FI3 for the visualization of epileptic seizures might be useful as an improved alternative for $\left[\mathrm{Ca}^{2+}\right]$ imaging in studying specific features of epileptic activity. 
Using 2PI, in vivo assessment of cerebral epileptic processes is warranted. In vivo imaging has so far mostly been limited to superficial cortical regions of rodent subjects. However, advances in endomicroscopy could provide the possibility to investigate deeper brain structures in vivo, such as the insular region [96]. Endomicroscopy is a technique in which a small optical fiber can be inserted into a region of interest to visualize the target tissue. Following its employment, two-photon endomicroscopy could assess functional and morphological characteristics of the target tissue. In addition to applying this technique to animal models, in vivo 2PI and endomicroscopy could be applied for human research. Even though the possibility to capture a live seizure event in humans is unlikely, the profound effects of seizures on astrocytes, neurites, and microglia throughout the human brain could be visualized. In fact, in the field of neurosurgery, in vivo endomicroscopy is increasingly being adopted to visualize vascular structures and specific regions of interest [98]. This is an exciting prospect that could potentially revolutionize the way we evaluate and understand epilepsy.

2PI has been proven to be feasible in visualizing neurovascular changes in epileptogenesis. Further research may be aimed at exploring microvascular alterations and blood-brain barrier dysfunction, perhaps finding novel therapeutic targets by restoring adequate vasomotor control, which can be visualized using 2PI. Furthermore, the aggregation of lipofuscin in the neurovasculature could play a role in the pathophysiology of epilepsy, contributing to our understanding of the disorder.

2PI is also of interest for use in studying the pathophysiology of other neurological disorders, such as stroke, neurodegenerative disease, and traumatic brain injury. Hence, the results of 2PI described in this review may also contribute to a better understanding of these neurological disorders. Furthermore, the potential application of 2PI using the current two-photon endoscopes under development opens avenues for 2PI as an in vivo tool to visualize metabolic processes and individual cell characteristics. As such, $2 \mathrm{PI}$ endoscopes could contribute to a new approach to brain imaging.

\section{Conclusions}

Over the past two decades, several studies have assessed pathomechanisms associated with epilepsy using 2PI. These studies have undoubtedly contributed to our understanding of the disorder. Seizure propagation; changes in cellular morphology, signaling, and activity; and metabolic alterations can be assessed using 2PI. Furthermore, these studies have described with great temporal accuracy the changes in the neurovasculature that accompany seizure formation as well as during ictal events, leading to novel insights. The application of 2PI provides ample possibilities for future research, most interestingly on human brains. Its applications also stretch beyond the field of epilepsy research.

Supplementary Materials: The following are available online at https:/ /www.mdpi.com/2076-341 7/11/5/2404/s1, Table S1: Epileptic Network Propagation; Table S2: Microglia; Table S3: Astrocytes; Table S4: Neurovasculature; Table S5: Neurites; Table S6: Neurometabolism.

Author Contributions: Conceptualization, K.R., M.v.Z., and R.v.L.; methodology, L.K., R.H., K.R., M.v.Z., and R.v.L.; validation, L.K. and R.H.; formal analysis, L.K. and R.H.; investigation, L.K. and R.H.; data curation, G.H., O.S., K.R., D.K., M.v.Z., and R.v.L.; writing—original draft preparation, L.K. and R.H.; writing-review and editing, G.H., O.S., K.R., D.K., M.v.Z., and R.v.L.; supervision, G.H., O.S., K.R., D.K., M.v.Z., and R.v.L.; project administration, M.v.Z. and R.v.L. All authors have read and agreed to the published version of the manuscript.

Funding: This research received no external funding.

Institutional Review Board Statement: Not applicable.

Informed Consent Statement: Not applicable.

Data Availability Statement: Not applicable.

Conflicts of Interest: The authors declare no conflict of interest. 


\section{References}

1. Svoboda, K.; Yasuda, R. Principles of Two-Photon Excitation Microscopy and Its Applications to Neuroscience. Neuron 2006, 50, 823-839. [CrossRef]

2. Kapsokalyvas, D.; van Zandvoort, M.A. Molecular Imaging in Oncology: Advanced Microscopy Techniques. Recent Results Cancer Res 2020, 216, 533-561. [CrossRef]

3. Helmchen, F.; Denk, W. Deep tissue two-photon microscopy. Nat. Methods 2005, 2, 932-940. [CrossRef]

4. Zipfel, W.R.; Williams, R.M.; Webb, W.W. Nonlinear magic: Multiphoton microscopy in the biosciences. Nat. Biotechnol. 2003, 21, 1369-1377. [CrossRef] [PubMed]

5. Douma, K.; Megens, R.T.; Reitsma, S.; Prinzen, L.; Slaaf, D.W.; van Zandvoort, M.A. Two-photon lifetime imaging of fluorescent probes in intact blood vessels: A window to sub-cellular structural information and binding status. Miscrosc. Res. Tech 2007, 70, 467-475. [CrossRef] [PubMed]

6. Beghi, E. Addressing the burden of epilepsy: Many unmet needs. Pharmacol. Res. 2016, 107, 79-84. [CrossRef]

7. Moshé, S.; Perucca, E.; Ryvlin, R.; Tomson, T. Epilepsy: New advances. Lancet 2015, 385, 884-898. [CrossRef]

8. Chen, Z.; Brodie, M.J.; Liew, D.; Kwan, P. Treatment Outcomes in Patients With Newly Diagnosed Epilepsy Treated With Established and New Antiepileptic Drugs. JAMA Neurol. 2018, 75, 279-286. [CrossRef]

9. Garbelli, R.; De Bock, F.; Medici, V. PDGFR $\beta(+)$ cells in human and experimental neuro-vascular dysplasia and seizures. Neuroscience 2015, 306, 18-27. [CrossRef]

10. Rigau, V.; Morin, M.; Rousset, M.C.; De Bock, F.; Lebrun, A.; Coubes, P.; Picot, M.C.; Baldy-Moulinier, M.; Bockaert, J.; Crespel, A.; et al. Angiogenesis is associated with blood-brain barrier permeability in temporal lobe epilepsy. Brain 2007, 130, 1942-1956. [CrossRef] [PubMed]

11. Kastanauskaite, A.; Alonso-Nanclares, L.; Blazquez-Llorca, L.; Pastor, J.; Sola, R.G.; Defelipe, J. Alterations of the microvascular network in sclerotic hippocampi from patients with epilepsy. J. Neuropathol. Exp. Neurol. 2009, 68, 939-950. [CrossRef]

12. Heinemann, U.; Kaufer, D.; Friedman, A. Blood-brain barrier dysfunction, TGF $\beta$ signaling, and astrocyte dysfunction in epilepsy. Glia 2012, 60, 1251-1257. [CrossRef] [PubMed]

13. Haeren, R.H.; Hartmans, S.A.; De Mey, J.; Hoogland, G.; Dings, J.T.; Schijns, O.E.; Van Kuijk, S.M.; Rijkers, K.; Schiffers, P.H.; van Overbeeke, J.J. Cerebral Artery Vasoconstriction is Endothelin-1 Dependent Requiring Neurogenic and Adrenergic Crosstalk. Curr. Neurovasc. Res. 2018, 14, 306-315. [CrossRef] [PubMed]

14. Van Vliet, E.A.; Auraujo, S.D.; Redeker, S.; Van Schaik, R.; Aronica, E.; Gorter, J.A. Blood-brain barrier leakage may lead to progression of temporal lobe epilepsy. Brain 2006, 130, 521-534. [CrossRef]

15. Van Vliet, E.; Aronica, E.; Gorter, J. Blood-brain barrier dysfunction, seizures and epilepsy. Semin. Cell Dev. Biol. 2015, 38, 26-34. [CrossRef]

16. Van Vliet, E.A.; Otte, W.M.; Wadman, W.J.; Aronica, E.; Kooij, G.; De Vries, H.E.; Dijkhuizen, R.M.; Gorter, J.A. Blood-brain barrier leakage after status epilepticus in rapamycin-treated rats II: Potential mechanisms. Epilepsia 2015, 57, 70-78. [CrossRef] [PubMed]

17. Brigo, F.; Lattanzi, S. Poststroke seizures as stroke mimics: Clinical assessment and management. Epilepsy Behav. 2020, 104, 106297. [CrossRef] [PubMed]

18. Ndode-Ekane, X.E.; Hayward, N.M.; Gröhn, O.; Pitkänen, A. Vascular changes in epilepsy: Functional consequences and association with network plasticity in pilocarpine-induced experimental epilepsy. Neuroscience 2010, 116, 312-332. [CrossRef] [PubMed]

19. Haeren, R.H.; Rijkers, K.; Schijns, O.E.; Dings, J.T.; Hoogland, G.; van Zandvoort, M.A.; Vink, H.; van Overbeeke, J.J. In vivo assessment of the human cerebral microcirculation and its glycocalyx: A technical report. J. Neurosci. Methods 2018, 303, 114-125. [CrossRef]

20. Czerska, M.; Mikolajewska, K.; Zielinski, M.; Gromadzinska, J.; Wasowicz, W. Today's oxidative stress markers. Med. Pr. 2015, 66, 393-405. [CrossRef] [PubMed]

21. Hakvoort, K.; Otto, L.; Haeren, R.H.; Hoogland, G.; Schijns, O.E.; Vink, H.; Klein, D.; van Zandvoort, M.A.; Rijkers, K. Shedding light on human cerebral lipofuscin: An explorative study on identification and quantification. J. Comp. Neurol. 2021, 529, 605-615. [CrossRef]

22. García, A.M.; Kun, A.; Calero, O.; Medina, M.; Calero, M. An overview of the role of lipofuscin in age-related neurodegeneration. Front. Neurosci. 2018, 12, 464. [CrossRef] [PubMed]

23. Douma, K.; Oostendorp, M.; Slaaf, D.W.; Post, M.J.; Backes, W.H.; van Zandvoort, M.A. Evaluation of magnetic resonance vessel size imaging by two-photon laser scanning microscopy. Magn. Reson. Med. 2010, 63, 930-939. [CrossRef]

24. Haeren, R.H.; Van de Ven, S.E.; van Zandvoort, M.A.; Vink, H.; van Overbeeke, J.J.; Hoogland, G.; Rijkers, K. Assessment and Imaging of the Cerebrovascular Glycocalyx. Curr. Neurovasc. Res. 2016, 13, 249-260. [CrossRef] [PubMed]

25. Hillman, E.M.C. Optical brain imaging in vivo: Techniques and applications from animal to man. J. Biomed. Opt. 2007, 12, 051402. [CrossRef] [PubMed]

26. Datta, R.; Heaster, T.M.; Sharick, J.T.; Gillette, A.A.; Skala, M.C. Fluorescence lifetime imaging microscopy: Fundamentals and advances in instrumentation, analysis, and applications. J. Biomed. Opt. 2020, 25, 1-43. [CrossRef]

27. Hoogland, G.; Hens, J.J.; De Wit, M.; van Veelen, C.W.; van Huffelen, A.C.; Gispen, W.H.; de Graan, P.N. Glutamate and gamma-aminobutyric acid content and release of synaptosomes from temporal lobe epilepsy patients. J. Neurosci. Res. 2000, 60, 686-695. [CrossRef] 
28. Schijns, O.E.; Karaca, Ü.; Andrade, P.; De Nijs, L.; Küsters, B.; Peeters, A.; Dings, J.T.; Pannek, H.; Ebner, A.; Rijkers, K.; et al. Hippocampal GABA transporter distribution in patients with temporal lobe epilepsy and hippocampal sclerosis. J. Chem. Neuroanat. 2015, 68, 39-44. [CrossRef]

29. Upreti, C.; Otero, R.; Partida, C.; Skinner, F.; Thakker, R.; Pachecho, L.; Zhou, Z.; Maglakelidze, G.; Veliskova, J.; Romanovicz, D.; et al. Altered neurotransmitter release, vesicle recycling and presynaptic structure in the pilocarpine model of temporal lobe epilepsy. Brain 2012, 135, 869-885. [CrossRef]

30. Rossi, L.F.; Kullmann, D.M.; Wykes, R.C. The Enlightened Brain: Novel Imaging Methods Focus on Epileptic Networks at Multiple Scales. Front. Cell. Neurosci. 2018, 12, 82. [CrossRef]

31. Liou, J.Y.; Ma, H.; Wenzel, M.; Zhao, M.; Baird-Daniel, E.; Smith, E.H.; Daniel, A.; Emerson, R.; Yuste, R.; Schwartz, T.H.; et al. Role of inhibitory control in modulating focal seizure spread. Brain 2018, 141, 2083-2097. [CrossRef] [PubMed]

32. Wenzel, M.; Hamm, J.P.; Peterka, D.S.; Yuste, R. Acute Focal Seizures Start As Local Synchronizations of Neuronal Ensembles. J. Neurosci. 2019, 39, 8562-8575. [CrossRef]

33. Wenzel, M.; Hamm, J.P.; Peterka, D.S.; Yuste, R. Reliable and Elastic Propagation of Cortical Seizures In Vivo. Cell Rep. 2017, 19, 2681-2693. [CrossRef]

34. Lillis, K.P.; Kramer, M.A.; Mertz, J.; Staley, K.J.; White, J.A. Pyramidal cells accumulate chloride at seizure onset. Neurobiol. Dis. 2012, 47, 358-366. [CrossRef] [PubMed]

35. Cammarota, M.; Losi, G.; Chiavegato, A.; Zonta, M.; Carmignoto, G. Fast spiking interneuron control of seizure propagation in a cortical slice model of focal epilepsy. J. Physiol. 2013, 591, 807-822. [CrossRef] [PubMed]

36. Petrucco, L.; Pracucci, E.; Brondi, M.; Ratto, G.M.; Landi, S. Epileptiform activity in the mouse visual cortex interferes with cortical processing in connected areas. Sci. Rep. 2017, 7, 40054. [CrossRef] [PubMed]

37. Muldoon, S.F.; Villette, V.; Tressard, T.; Malvache, A.; Reichinnek, S.; Bartolomei, F.; Cossart, R. GABAergic inhibition shapes interictal dynamics in awake epileptic mice. Brain 2015, 138, 2875-2890. [CrossRef]

38. Müller, B.J.; Zhdanov, A.V.; Borisov, S.M.; Foley, T.; Okkelman, I.A.; Tsytsarev, V.; Tang, Q.; Erzurumlu, R.S.; Chen, Y.; Zhang, H.; et al. Nanoparticle-Based Fluoroionophore for Analysis of Potassium Ion Dynamics in 3D Tissue Models and In Vivo. Adv. Funct. Mater. 2018, 28, 1704598. [CrossRef]

39. Cozzolino, O.; Sicca, F.; Paoli, E.; Trovato, F.; Santorelli, F.M.; Ratto, G.M.; Marchese, M. Evolution of Epileptiform Activity in Zebrafish by Statistical-Based Integration of Electrophysiology and 2-Photon Ca2+ Imaging. Cells 2020, 9, 769. [CrossRef] [PubMed]

40. Kerekes, B.P.; Tóth, K.; Kaszás, A.; Chiovini, B.; Szadai, Z.; Szalay, G.; Pálfi, D.; Bagó, A.; Spitzer, K.; Rózsa, B.; et al. Combined two-photon imaging, electrophysiological, and anatomical investigation of the human neocortex in vitro. Neurophotonics 2014, 1, 011013c. [CrossRef]

41. Lillis, K.P.; Wang, Z.; Mail, M.; Zhao, G.Q.; Berdichevsky, Y.; Bacskai, B.; Staley, K.J. Evolution of network synchronization during early epileptogenesis parallels synaptic circuit alterations. J. Neurosci. 2015, 35, 9920-9934. [CrossRef]

42. Feng, L.; Murugan, M.; Bosco, D.B.; Liu, Y.; Peng, J.; Worrell, G.A.; Wang, H.; Ta, L.E.; Richardson, J.R.; Shen, Y.; et al. Microglial proliferation and monocyte infiltration contribute to microgliosis following status epilepticus. Glia 2019, 67, 1434-1448. [CrossRef]

43. Eyo, U.B.; Mo, M.; Yi, M.H.; Murugan, M.; Liu, J.; Yarlagadda, R.; Margolis, D.J.; Xu, P.; Wu, L.J. P2Y12R-Dependent Translocation Mechanisms Gate the Changing Microglial Landscape. Cell Rep. 2018, 23, 959-966. [CrossRef] [PubMed]

44. Eyo, U.B.; Peng, J.; Murugan, M.; Mo, M.; Lalani, A.; Xie, P.; Xu, P.; Margolis, D.J.; Wu, L.J. Regulation of physical microglia-neuron interactions by fractalkine signaling after status epilepticus. eNeuro 2016, 3, ENEURO.0209-16.2016. [CrossRef] [PubMed]

45. Avignone, E.; Lepleux, M.; Angibaud, J.; Nägerl, U.V. Altered morphological dynamics of activated microglia after induction of status epilepticus. J. Neuroinflamm. 2015, 12, 202. [CrossRef]

46. Eyo, U.B.; Peng, J.; Swiatkowski, P.; Mukherjee, A.; Bispo, A.; Wu, L.J. Neuronal hyperactivity recruits microglial processes via neuronal NMDA receptors and microglial P2Y12 receptors after status epilepticus. J. Neurosci. 2014, 34, 10528-10540. [CrossRef] [PubMed]

47. Verdugo, C.D.; Myren-Svelstad, S.; Aydin, E.; Van Hoeymissen, E.; Deneubourg, C.; Vanderhaeghe, S.; Vancraeynest, J.; Pelgrims, R.; Cosacak, M.I.; Muto, A.; et al. Glia-neuron interactions underlie state transitions to generalized seizures. Nat. Commun. 2019, 10, 1-13. [CrossRef]

48. Chugh, D.; Ekdahl, C.T. Interactions Between Microglia and Newly Formed Hippocampal Neurons in Physiological and Seizure-Induced Inflammatory Environment. Brain Plast. 2016, 1, 215-221. [CrossRef] [PubMed]

49. Guo, N.; Zou, J.; Wong, M. Rapamycin attenuates acute seizure-induced astrocyte injury in mice in vivo. Sci. Rep. 2017, 7, 2867. [CrossRef]

50. Plata, A.; Lebedeva, A.; Denisov, P.; Nosova, O.; Postnikova, T.Y.; Pimashkin, A.; Brazhe, A.; Zaitsev, A.V.; Rusakov, D.A.; Semyanov, A. Astrocytic Atrophy Following Status Epilepticus Parallels Reduced Ca ${ }^{2+}$ Activity and Impaired Synaptic Plasticity in the Rat Hippocampus. Front. Mol. Neurosci. 2018, 11, 215. [CrossRef]

51. Raimondo, J.V.; Tomes, H.; Irkle, A.; Kay, L.; Kellaway, L.; Markram, H.; Millar, R.P.; Akerman, C.J. Tight coupling of astrocyte pH dynamics to epileptiform activity revealed by genetically encoded pH sensors. J. Neurosci. 2016, 36, 7002-7013. [CrossRef] [PubMed]

52. Kang, N.; Xu, J.; Xu, Q.; Nedergaard, M.; Kang, J. Astrocytic glutamate release-induced transient depolarization and epileptiform discharges in hippocampal CA1 pyramidal neurons. J. Neurophysiol. 2005, 94, 4121-4130. [CrossRef] 
53. Tian, G.F.; Azmi, H.; Takano, T.; Xu, Q.; Peng, W.; Lin, J.; Oberheim, N.A.; Lou, N.; Wang, X.; Zielke, H.R.; et al. An astrocytic basis of epilepsy. Nat. Med. 2005, 11, 973-981. [CrossRef] [PubMed]

54. Ding, S.; Fellin, T.; Zhu, Y.; Lee, S.Y.; Auberson, Y.P.; Meaney, D.F.; Coulter, D.A.; Carmignoto, G.; Haydon, P.G. Enhanced astrocytic Ca2+ signals contribute to neuronal excitotoxicity after status epilepticus. J. Neurosci. 2007, 27, 10674-10684. [CrossRef] [PubMed]

55. Nikolic, L.; Shen, W.; Nobili, P.; Virenque, A.; Ulmann, L.; Audinat, E. Blocking TNF $\alpha$-driven astrocyte purinergic signaling restores normal synaptic activity during epileptogenesis. Glia 2018, 66, 2673-2683. [CrossRef]

56. Gómez-Gonzalo, M.; Losi, G.; Chiavegato, A.; Zonta, M.; Cammarota, M.; Brondi, M.; Vetri, F.; Uva, L.; Pozzan, T.; de Curtis, M.; et al. An excitatory loop with astrocytes contributes to drive neurons to seizure threshold. PLoS Biol. 2010, 8, e1000352. [CrossRef]

57. Zhang, C.; Tabatabaei, M.; Bélanger, S.; Girouard, H.; Moeini, M.; Lu, X.; Lesage, F. Astrocytic endfoot Ca ${ }^{2+}$ correlates with parenchymal vessel responses during 4-AP induced epilepsy: An in vivo two-photon lifetime microscopy study. J. Cereb. Blood Flow Metab. 2019, 39, 260-271. [CrossRef] [PubMed]

58. Zhang, C.; Moeini, M.; Lesage, F. Spatial landscape of oxygen in and around microvasculature during epileptic events. Neurophotonics 2017, 4, 10501. [CrossRef]

59. Zhao, M.; Nguyen, J.; Ma, H.; Nishimura, N.; Schaffer, C.B.; Schwartz, T.H. Preictal and ictal neurovascular and metabolic coupling surrounding a seizure focus. J. Neurosci. 2011, 31, 13292-13300. [CrossRef]

60. Hirase, H.; Creso, J.; Buzsáki, G. Capillary level imaging of local cerebral blood flow in bicuculline-induced epileptic foci. Neuroscience 2004, 128, 209-216. [CrossRef]

61. Lim, H.K.; You, N.; Bae, S.; Kang, B.M.; Shon, Y.M.; Kim, S.G.; Suh, M. Differential contribution of excitatory and inhibitory neurons in shaping neurovascular coupling in different epileptic neural states. J. Cereb. Blood Flow Metab. 2020, $271678 X 20934071$. [CrossRef]

62. Kelly, T.; Beck, H. Functional properties of granule cells with hilar basal dendrites in the epileptic dentate gyrus. Epilepsia 2017, 58, 160-171. [CrossRef]

63. Rensing, N.; Ouyang, Y.; Yang, X.F.; Yamada, K.A.; Rothman, S.M.; Wong, M. In vivo imaging of dendritic spines during electrographic seizures. Ann. Neurol. 2005, 58, 888-898. [CrossRef] [PubMed]

64. Guo, N.; Arnspiger, S.; Rensing, N.R.; Wong, M. Brief seizures cause dendritic injury. Neurobiol. Dis. 2012, 45, 348-355. [CrossRef]

65. Yaseen, M.A.; Sutin, J.; Wu, W.; Fu, B.; Uhlirova, H.; Devor, A.; Boas, D.A.; Sakadžić, S. Fluorescence lifetime microscopy of $\mathrm{NADH}$ distinguishes alterations in cerebral metabolism in vivo. Biomed. Opt. Express 2017, 8, 2368-2385. [CrossRef]

66. Chia, T.H.; Williamson, A.; Spencer, D.D.; Levene, M.J. Multiphoton fluorescence lifetime imaging of intrinsic fluorescence in human and rat brain tissue reveals spatially distinct NADH binding. Opt. Express 2008, 16, 4237-4249. [CrossRef] [PubMed]

67. Prager, O.; Kamintsky, L.; Hasam-Henderson, L.A.; Schoknecht, K.; Wuntke, V.; Papageorgiou, I.; Swolinsky, J.; Muoio, V.; Bar-Klein, G.; Vazana, U.; et al. Seizure-induced microvascular injury is associated with impaired neurovascular coupling and blood-brain barrier dysfunction. Epilepsia 2019, 60, 322-336. [CrossRef] [PubMed]

68. Ogaki, A.; Ikegaya, Y.; Koyama, R. Vascular Abnormalities and the Role of Vascular Endothelial Growth Factor in the Epileptic Brain. Front. Pharmacol. 2020, 11, 1-8. [CrossRef] [PubMed]

69. Bush, P.G.; Wokosin, D.L.; Hall, A.C. Two-versus one photon excitation laser scanning microscopy: Critical importance of excitation wavelength. Front. Biosci. 2007, 12, 2646-2657. [CrossRef] [PubMed]

70. Shemesh, O.A.; Linghu, C.; Piatkevich, K.D.; Goodwin, D.; Celiker, O.T.; Gritton, H.J.; Romano, M.F.; Gao, R.; Yu, C.C.; Tseng, H.A.; et al. Precision Calcium Imaging of Dense Neural Populations via a Cell-Body-Targeted Calcium Indicator. J. Clean. Prod. 2020, 107, 470-486. [CrossRef]

71. Scharfman, H.E. The neurobiology of epilepsy. Curr. Neurol. Neurosci. Rep. 2007, 7, 348-354. [CrossRef]

72. Ellis-Davies, G.C.R. Two-Photon Uncaging of Glutamate. Front. Synaptic Neurosci. 2019, 10, 48. [CrossRef]

73. Warther, D.; Gug, S.; Specht, A.; Bolze, F.; Nicoud, J.F.; Mourot, A.; Goeldner, M. Two-photon uncaging: New prospects in neuroscience and cellular biology. Bioorg. Med. Chem. 2010, 18, 7753-7758. [CrossRef]

74. Proper, E.A.; Hoogland, G.; Kappen, S.M.; Jansen, G.H.; Rensen, M.G.; Schrama, L.H.; van Veelen, C.W.; van Rijen, P.C.; van Nieuwenhuizen, O.; Gispen, W.H.; et al. Distribution of glutamate transporters in the hippocampus of patients with pharmaco-resistant temporal lobe epilepsy. Brain 2002, 125, 32-43. [CrossRef]

75. Somjen, G. Ions in the Brain; Oxford University Press: Oxford, UK, 2004.

76. Healthline Epilepsy: Causes, Symptoms, Treatment, and More. Available online: https://www.healthline.com/health/epilepsy\# epilepsy-triggers (accessed on 5 November 2020).

77. McPhee, S.; Hammer, G. Pathophysiology of Disease; McGraw-Hill: New York, NY, USA, 2014.

78. Maharathi, B.; Wlodarski, R.; Bagla, S.; Asano, E.; Hua, J.; Patton, J.; Loeb, J.A. Interictal spike connectivity in human epileptic neocortex. Clin. Neurophysiol. 2019, 130, 270-279. [CrossRef]

79. Coulter, D.A.; Steinhäuser, C. Role of astrocytes in epilepsy. Cold Spring Harb. Perspect. Med. 2015, 5, a022434. [CrossRef]

80. Müller, J.; Timmermann, A.; Müller, H.; Steinhäuser, C.; Bedner, P. Astrocytic GABA Accumulation in Experimental Temporal Lobe Epilepsy. Front. Neurol. 2020, 11, 614923. [CrossRef] [PubMed]

81. Puttachary, S.; Sharma, S.; Stark, S.; Thippeswamy, T. Seizure-induced oxidative stress in temporal lobe epilepsy. Biomed. Res. Int. 2015, 2015, 1-20. [CrossRef] [PubMed] 
82. Merelli, A.; Repetto, M.; Lazarowksi, A.; Auzmendi, J. Hypoxia, Oxidative Stress, and Inflammation: Three Faces of Neurodegenerative Diseases. J. Alzheimers Dis. 2020, 1-18. [CrossRef]

83. Katerji, M.; Filippova, M.; Duerksen-Hughes, P. Approaches and Methods to Measure Oxidative Stress in Clinical Samples: Research Applications in the Cancer Field. Oxid. Med. Cell. Longev. 2019, 2019, 1-29. [CrossRef]

84. Terman, A.; Brunk, U.T. Lipofuscin. Int. J. Biochem. Cell Biol. 2004, 36, 1400-1404. [CrossRef] [PubMed]

85. Tohma, H.; Hepworth, A.R.; Shavlakadze, T.; Grounds, M.D.; Arthur, P.G. Quantification of ceroid and lipofuscin in skeletal muscle. J. Histochem. Cytochm. 2011, 59, 769-779. [CrossRef]

86. Merlo, S.; Nakayama, A.B.S.; Brusco, J.; Rossi, M.A.; Carlotti, C.G.; Moreira, J.E. Lipofuscin Granules in the Epileptic Human Temporal Neocortex with Age. Ultrastruct. Pathol. 2015, 39, 378-384. [CrossRef]

87. Kohlschütter, A.; Schulz, A. CLN2 Disease (Classic Late Infantile Neuronal Ceroid Lipofuscinosis). Pediatr. Endocrinol. Rev. 2016, 13, 682-688. [PubMed]

88. Liu, J.Y.; Reeves, C.; Diehl, B.; Coppola, A.; Al-Hajri, A.; Hoskote, C.; Al Maghairy, S.; Tachrount, M.; Groves, M.; Michalak, Z.; et al. Early Lipofuscin Accumulation in Frontal Lobe Epilepsy. Ann. Neurol. 2016, 80, 882-895. [CrossRef] [PubMed]

89. Kim, H.C.; Bing, G.; Jhoo, W.K.; Kim, W.K.; Shin, E.J.; Park, E.S.; Choi, Y.S.; Lee, D.W.; Shin, C.Y.; Ryu, J.R.; et al. Oxidative damage causes formation of lipofuscin-like substances in the hippocampus of the senescence-accelerated mouse after kainate treatment. Behav. Brain Res. 2002, 131, 211-220. [CrossRef]

90. Ristic, A.J.; Savić, D.; Sokić, D.; Pristov, J.; Nestorov, J.; Baščarević, V.; Raičević, S.; Savić, S.; Spasojević, I. Hippocampal antioxidative system in mesial temporal lobe epilepsy. Epilepsia 2015, 56, 789-799. [CrossRef]

91. Yilmazer-Hanke, D.M.; Wolf, H.K.; Schramm, J.; Elger, C.E.; Wiestler, O.D.; Blümcke, I. Subregional Pathology of the Amygdala Complex and Entorhinal Region in Surgical Specimens From Patients With Pharmacoresistant Temporal Lobe Epilepsy. J. Neuropathol. Exp. Neurol. 2000, 59, 907-920. [CrossRef]

92. Cho, S.; Park, E.; Telliyan, T.; Baker, A.; Reid, A.Y. Zebrafish model of posttraumatic epilepsy. Epilepsia 2020, 61, 1774-1785. [CrossRef] [PubMed]

93. Walcott, B.P.; Peterson, R.T. Zebrafish models of cerebrovascular disease. J. Cereb. Blood Flow Metab. 2014, 34, 571-577. [CrossRef] [PubMed]

94. Yaksi, E.; Jamali, A.; Verdugo, C.D.; Jurisch-Yaksi, N. Past, present and future of zebrafish in epilepsy research. FEBS J. 2021. [CrossRef]

95. Koletar, M.M.; Dorr, A.; Brown, M.E.; McLaurin, J.; Stefanovic, B. Refinement of a chronic cranial window implant in the rat for longitudinal in vivo two-photon fluorescence microscopy of neurovascular function. Sci. Rep. 2019, 9, 5499. [CrossRef]

96. Qin, Z.; Chen, C.; He, S.; Wang, Y.; Tam, K.F.; Ip, N.Y.; Qu, J.Y. Adaptive optics two-photon endomicroscopy enables deep-brain imaging at synaptic resolution over large volumes. Sci. Adv. 2020, 6, eabc6521. [CrossRef]

97. Steinmetz, N.A.; Buetfering, C.; Lecoq, J.; Lee, C.R.; Peters, A.J.; Jacobs, E.A.K.; Coen, P.; Ollerenshaw, D.R.; Valley, M.T.; De Vries, S.E.J.; et al. Aberrant cortical activity in multiple GCaMP6-expressing transgenic mouse lines. eNeuro 2017, 4. [CrossRef]

98. Sankar, T.; Delaney, P.M.; Ryan, R.W.; Eschbacher, J.; Abdelwahab, M.; Nakaji, P.; Coons, S.W.; Scheck, A.C.; Smith, K.A.; Spetzler, R.F.; et al. Miniaturized handheld confocal microscopy for neurosurgery. Neurosurgery 2010, 66, 410-418. [CrossRef] 